\title{
rd of Decision
}

To Remove or Modify the Survey and Manage Mitigation Measure Standards and Guidelines

in Forest Service and Bureau of Land Management Planning

Documents Within the Range of the Northern Spotted Owl 
The U.S. Department of Agriculture prohibits discrimination in all its programs and activities on the basis of race, color, national origin, sex, religion, age, disability, political beliefs, sexual orientation, or marital or family status. (Not all prohibited bases apply to all programs.) Persons with disabilities who require alternative means for communication of program information (Braille, large print, audiotape, etc.) should contact USDA's TARGET Center at 202-720-2600 (voice and TDD). To file a complaint of discrimination, write USDA, Director, Office of Civil Rights, Room 326-W, Whitten Building, 1400 Independence Avenue, SW, Washington, DC 20250-9410 or call 202-720-5694 (voice or TDD). USDA is an equal opportunity provider and employer.

As the Nation's principal conservation agency, the Department of the Interior has responsibility for most of our nationally owned public lands and natural resources. This includes fostering the wisest use of our land and water resources, protecting our fish and wildlife, preserving the environmental and cultural values of our national parks and historical places, and providing for the enjoyment of life through outdoor recreation. The department assesses our energy and mineral resources and works to assure that their development is in the best interest of all our people. The Department also has a major responsibility for American Indian reservation communities and for people who live in Island Territories under U.S. administration.

\author{
BLM Library \\ Denver Federal Center \\ Bldg. 50, OC-521 \\ P.O. Box 25047 \\ Denver, CO 80225
}

Cover artwork compliments of Elizabeth I. Gayner. Drawing includes the Great gray owl (Strix nebulosa), an orchid (Cypripedium montanum), a mushroom (Gyromitra californica), and a snail (Monadenia fidelis). 


\title{
RECORD OF DECISION
}

\section{to \\ Remove or Modify the Survey and Manage Mitigation Measure Standards and Guidelines}

\begin{abstract}
in
Forest Service and Bureau of Land Management Planning Documents Within the Range of the Northern Spotted Owl
\end{abstract}

March 2004 


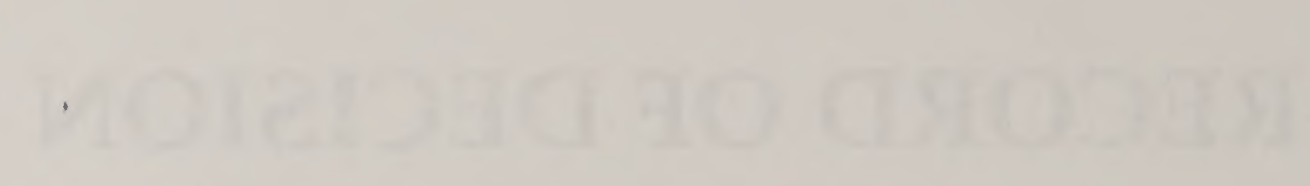

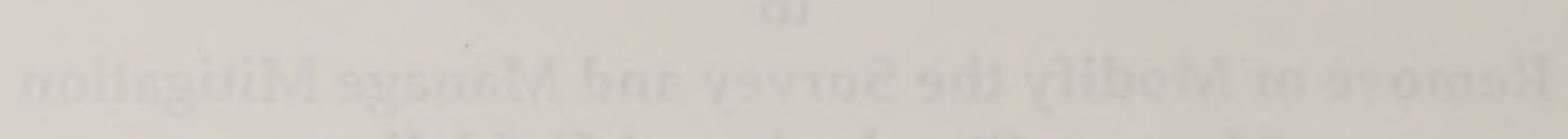

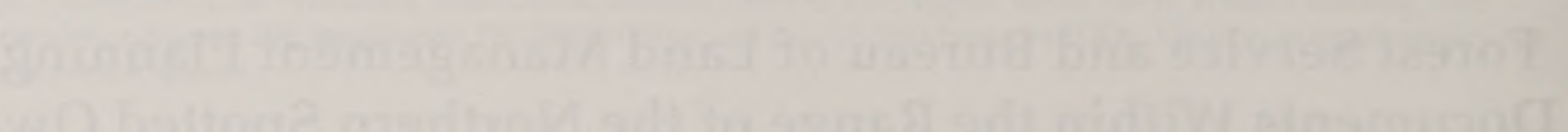




\section{Table of Contents}

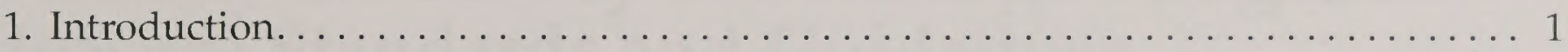

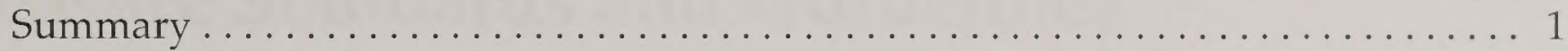

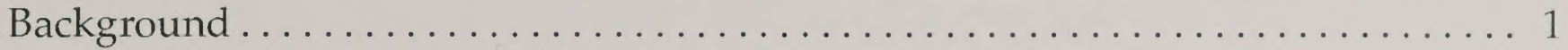

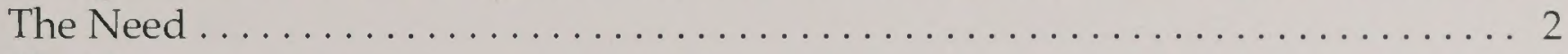

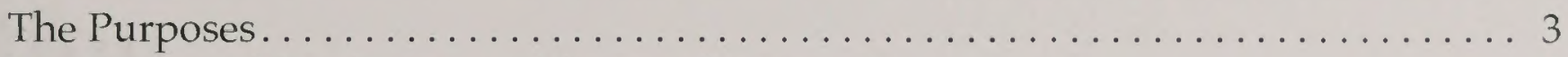

Supplemental Environmental Impact Statement. ................... 4

The Alternatives . . . . . . . . . . . . . . . . . . . . . . . . . . . 4

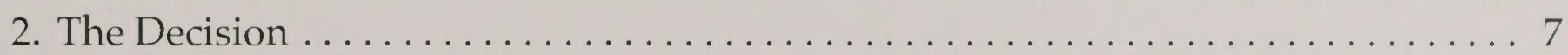

Plans Amended. ...................................... 8

Application to Contracts, Permits, and Special Use Authorizations .......... 8

Application of this Decision to On-going and Current Management Activities.... . 9

3. Reasons for the Decision ................................. 9

Meeting the Purposes Identified in the Final SEIS . . . . . . . . . . . . . 9

Summary of the Reasons for the Decision . . . . . . . . . . . . . . . 13

4. Other Alternatives Considered in Detail and Reasons They Were Not Selected ... 14 Alternative 1, No-Action . . . . . . . . . . . . . . . . . . . . . . . . . . . . 14

Alternative 3, Modifed Survey and Manage . . . . . . . . . . . . . . . . . . . 15

Mitigation of Adverse Environmental Consequences Associated with this Decision15

5. Findings . . . . . . . . . . . . . . . . . . . . . . . . . 16

National Environmental Policy Act (NEPA) . . . . . . . . . . . . . . . . 16

National Forest Management Act (NFMA) . . . . . . . . . . . . . . . 18

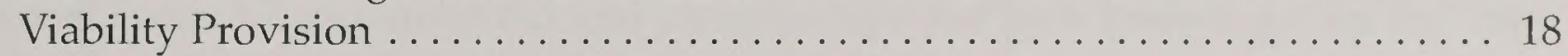

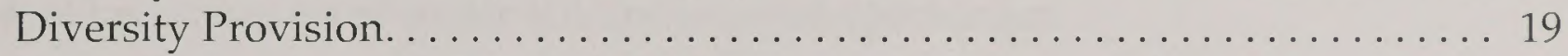

Forest Service Land and Resource Management Plan Amendments... . . . . . 20

Endangered Species Act . . . . . . . . . . . . . . . . . . . . . . . 21

Federal Land Policy and Management Act ..................... 23

Oregon and California Railroad and Coos Bay Wagon Road Grant Lands Act . . . 23 (O\&C Act)

Protection of Tribal Treaty Rights and Trust Resources ................ 23

Review by the Regional Interagency Executive Committee (RIEC) .......... 23

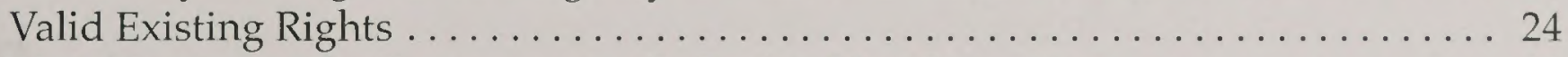

6. Identification of the Environmentally Preferable Alternative ............. 24

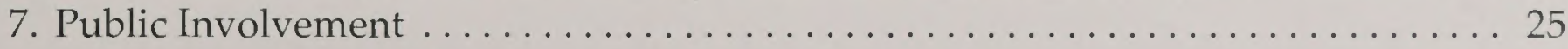

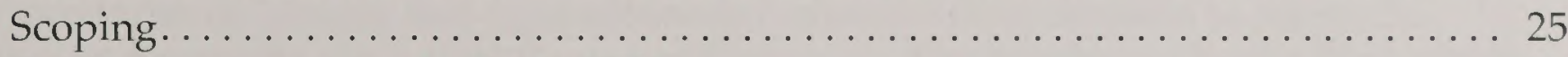

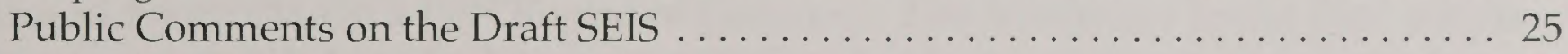

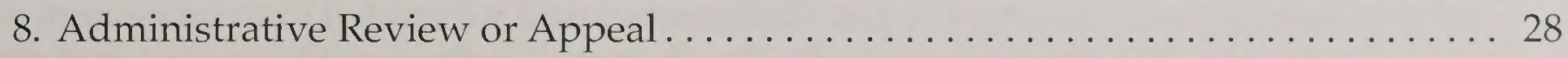

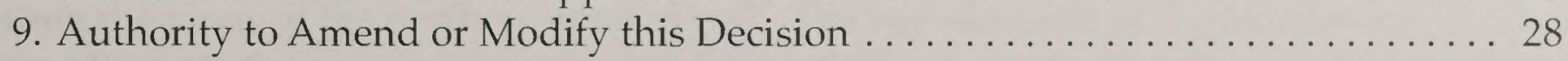

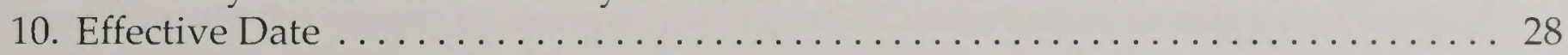

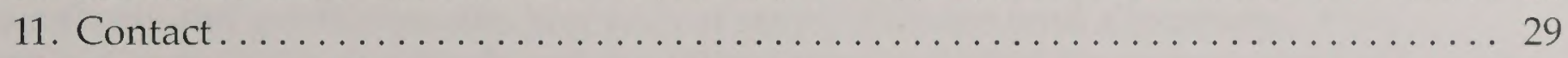

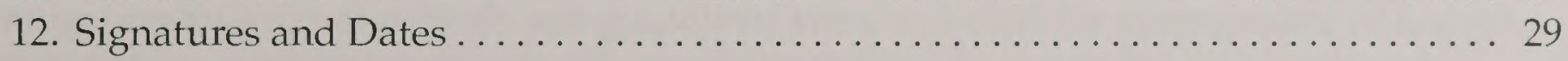




\section{RECORD OF DECISION}

to

\section{Remove or Modify the Survey and Manage Mitigation Measure Standards and Guidelines}

\section{Introduction}

\section{Summary}

In this Record of Decision we are amending a portion of the Northwest Forest Plan by removing the Survey and Manage Mitigation Measure Standards and Guidelines. This Decision applies to administrative units of the USDA Forest Service, the USDI Bureau of Land Management (BLM) (generally referred to as "the Agencies"), and the Coquille Tribe (approximately 5,400 acres of forest lands known as the Coquille Forest) within the range of the northern spotted owl. Our Decision is to select Alternative 2 in the January 2004 Final Supplemental Environmental Impact Statement to Remove or Modify the Survey and Manage Mitigation Measure Standards and Guidelines (Final SEIS). This Decision will:

1. Continue to provide for diversity of plant and animal communities in accordance with the National Forest Management Act and conserve rare and little known species that may be at risk of becoming listed under the Endangered Species Act.

2. Reduce the Agencies' cost, time, and effort associated with rare and little known species conservation.

3. Restore the Agencies' ability to achieve Northwest Forest Plan resource management goals and predicted timber outputs.

\section{Background}

The Secretaries of Interior and Agriculture documented their decision to adopt the Northwest Forest Plan in a 1994 Record of Decision'. The Northwest Forest Plan was for the management of habitat for late-successional and old-growth forest related species within the range of the northern spotted owl. The key elements of the Northwest Forest Plan are the system of reserves, the Aquatic Conservation Strategy, and various standards and guidelines affecting each of seven different land allocations. Also, mitigation measure standards and guidelines were included for management of known sites and for conducting site-specific, pre-habitat disturbing surveys and landscapescale surveys for about 400 rare and uncommon species. These are species that, either because of genuine rarity or because of a lack of information about them, the Agencies could not be absolutely certain they would be adequately protected by other elements of the Northwest Forest Plan. The standards and guidelines for these mitigation measures are known as Survey and Manage. They represent a cautious approach to rare species management that attempts to reduce risk to species by gathering exhaustive data prior to making a land management decision.

\footnotetext{
${ }^{1}$ The Northwest Forest Plan is formally known as "The Record of Decision for Amendments to Forest Service and Bureau of Land Management Planning Documents Within the Range of the Northern Spotted Owl and the Standards and Guidelines for Management of Habitat for Late-Successional and Old-Growth Related Species Within the Range of the Northern Spotted Owl."
} 
The Northwest Forest Plan was amended by the January 2001 Record of Decision for Amendments to the Survey and Manage, Protection Buffer, and other Mitigation Measures Standards and Guidelines. The 2001 amendment clarified and improved the management direction for the Survey and Manage Mitigation Measure Standards and Guidelines and established a process for changes based on new information, but retained the high cost surveys and known site management. Although the 1994 and 2001 Records of Decision actually amended 28 individual land and resource management plans, the overall resource management strategy has continued to be called the Northwest Forest Plan.

The Survey and Manage Mitigation Measure Standards and Guidelines currently provide procedures and requirements for the management of 4 arthropod functional groups and 296 rare and uncommon species within the Northwest Forest Plan area. Species include fungi, lichens, vascular plants, mollusks, bryophytes, and vertebrates. The Survey and Manage Mitigation Measure Standards and Guidelines include species that are closely associated with late-successional or old-growth forests and for which it is unknown if other elements of the Northwest Forest Plan (such as reserves or other standards and guidelines) provide a reasonable assurance of persistence. None of these species are currently listed or petitioned for listing as Threatened or Endangered under the Endangered Species Act.

Douglas Timber Operators, Inc., and American Forest Resource Council filed a lawsuit against the Secretaries of Agriculture and the Interior concerning the 2001 Record of Decision for Amendments to the Survey and Manage, Protection Buffer, and other Mitigation Measures Standards and Guidelines (Douglas Timber Operators, et al. v. Secretary of Agriculture, et al. Civil No. 01-6378-AA (D. Oregon)). The lawsuit alleges that the Survey and Manage amendments effectively transferred more than 81,000 acres of timber-producing forest land into permanent reserves. The lawsuit alleges that this transfer equates to a loss of 51 million board feet (MMBF) of timber sales per year in perpetuity and is, therefore, in violation of the substantive and procedural requirements of the Oregon and California Railroad and Coos Bay Wagon Road Grant Lands Act (O\&C Act), 43 U.S.C. $\$ 1181$ a, the National Forest Management Act (NFMA), 16 U.S.C. $\S 1600$, et seq., the Multiple-Use Sustained-Yield (MUSY) Act of 1960, 16 U.S.C. §528531, and the Federal Land Policy and Management Act (FLPMA), 43 U.S.C. §1701, et seq. On September 30, 2002, the Secretaries of Agriculture and the Interior entered into a settlement agreement with the plaintiffs. The agreement requires the Agencies to examine, in an SEIS, an alternative that removes the Survey and Manage mitigation requirements and instead relies on existing Forest Service and BLM special status species policies to provide protection for rare species. It also requires the Secretaries to issue a Record of Decision within 30 days after publication of the Final SEIS. The agreement does not stipulate the alternative to be selected.

\section{The Need}

The underlying needs to which the Agencies are responding are healthy forest ecosystems and a sustainable supply of timber and other forest products, to the extent these are frustrated by the Survey and Manage Mitigation Measure Standards and Guidelines.

Impacts of the Survey and Manage Mitigation Measure Standards and Guidelines have been greater than those anticipated when the mitigation measure was added to the SEIS for the Northwest Forest Plan in 1994. As a result, they are one of the factors frustrating the achievement of the stated goals of the Northwest Forest Plan "to protect the long-term health of our forests, our wildlife and our waterways.... [and] produce a predictable and sustainable level of timber sales and nontimber resources that will not degrade or destroy the environment." (USDA, USDI 1994a, p. 1-4 and USDA, USDI 1994b, p. 3.) 
Specifically, the Survey and Manage Mitigation Measure Standards and Guidelines substantially restrict the ability of the Agencies to conduct forest health treatments (i.e. fuels reduction, Late-Successional Reserve and riparian thinning) through exhaustive and time-consuming surveys and restrictive management prescriptions. They are also reducing the level of timber harvest that was predicted under the Northwest Forest Plan.

\section{The Purposes}

The purposes of this decision are to:

1. Comply with the terms of the Settlement Agreement by considering, in detail, an alternative that removes the Survey and Manage Mitigation Measure Standards and Guidelines.

The settlement agreement requires the Agencies to examine, in an SEIS, an alternative (Alternative 2 in the Final SEIS) that removes the Survey and Manage Mitigation Measure Standards and Guidelines and instead uses existing Forest Service and BLM Special Status Species Policies to achieve the goals of the Northwest Forest Plan through a more streamlined process. It also requires the Secretaries to issue a Record of Decision within 30 days after publication of the Final SEIS. However, the agreement does not stipulate the alternative to be selected, so this purpose is not included in the reasons for the decision.

2. Continue to provide for diversity of plant and animal communities in accordance with the National Forest Management Act and conserve rare and little known species that may be at risk of becoming listed under the Endangered Species Act.

It is policy in both the Forest Service and BLM to avoid taking actions that would lead to the listing of species under the Endangered Species Act. The Agencies meet this responsibility nationally through their Special Status Species Policies. These policies are found in U.S. Department of Agriculture Regulation 9500-4, Forest Service Manual 2670.32, and BLM Manual 6840.22. These policies share two principles: assist in the recovery of threatened and endangered species and implement management practices so that species do not become threatened or endangered because of federal actions. In addition, the Forest Service is required by the National Forest Management Act (NFMA) to "provide for diversity of plant and animal communities based on the suitability and capability of the specific land area in order to meet overall multiple-use objectives, and within the multiple-use objectives of a land management plan" (16 U.S.C. 1604(g)(3)(B)).

\section{Reduce the Agencies' cost, time, and effort associated with rare and little known species conservation.}

Agency funding is important to accomplishing overall management objectives. The annual cost of the Survey and Manage Program is projected at more than \$25 million under the Northwest Forest Plan. This is excessive, especially considering that none of the Survey and Manage species are currently listed as Threatened or Endangered under the Endangered Species Act. While progress at streamlining processes has been made in the last 2 years, some Survey and Manage processes are still overly complex and time consuming, leading to delays and stalled projects. These problems limit the Agencies' ability to meet policy objectives and divert money from other work including watershed restoration projects, fuel reduction projects, timber management projects, and projects designed to improve habitat for threatened, endangered, and other species. 
4. Restore the Agencies' ability to achieve Northwest Forest Plan resource management goals and predicted timber outputs.

Some species in Survey and Manage are so numerous or widespread that the acreage needed to protect them far exceeds that projected in previous analyses. Some project areas become dotted with dozens of known sites, severely reducing project size or making the entire project infeasible. The result has been to limit the Agencies' ability to restore forest health including fuel treatments to reduce the threat of catastrophic wildfire to watersheds, late-successional habitats, and communities at risk. This problem has also contributed to the Agencies' inability to achieve predictable and sustainable levels of timber outputs as envisioned in the Northwest Forest Plan.

\section{Supplemental Environmental Impact Statement}

This Decision is based on information and analysis in the Final SEIS to Remove or Modify the Survey and Manage Mitigation Measure Standards and Guidelines. The Final SEIS was prepared by the BLM and Forest Service. The Notice of Intent to prepare the Final SEIS was published in the Federal Register on October 21, 2002. The Final SEIS is a supplement to the 2000 Final SEIS for Amendments to the Survey and Manage, Protection Buffer, and other Mitigation Measures Standards and Guidelines as well as the 1994 Final SEIS on Management of Habitat for Late-Successional and Old-Growth Forest-Related Species Within the Range of the Northern Spotted Owl, referred to herein as the 1994 Northwest Forest Plan Final SEIS. The analysis in the Final SEIS, upon which this Record of Decision is based, built upon analysis in the 2000 Survey and Manage Final SEIS and the 1994 Northwest Forest Plan Final SEIS, particularly Appendix J-2 and the report of the Forest Ecosystem Management Assessment Team (FEMAT). Other research literature, agency records, and databases were searched, and other experts consulted, to provide the most updated and complete collection of information about these species as possible. These sources of information are referenced throughout the effects sections of the Final SEIS and are listed in the References section of the Final SEIS. For purposes of comparing the alternatives, the analysis in the Final SEIS assumed full implementation of the Northwest Forest Plan resource management goals and the current Probable Sale Quantity (PSQ) of $805 \mathrm{MMBF}$ of timber harvest. This provided a consistent base for estimating effects.

\section{The Alternatives}

Three alternatives were analyzed in detail in the Final SEIS (pp. 24-84) and were considered in this decision.

\section{Alternative 1}

Alternative 1, the No-Action Alternative, would retain the Survey and Manage Mitigation Measure Standards and Guidelines included in the 28 land and resource management plans within the range of the northern spotted owl.

Species in Survey and Manage are assigned to one of six management categories. Categories are based on: (1) relative rarity; (2) ability to reasonably and consistently locate occupied sites during surveys prior to habitat-disturbing activities; and, (3) the level of information known about the species or group of species. Categories A, B, and E contain the rare species. Categories C, D, and F contain the uncommon species. Species that are "rare" have a higher concern for persistence than species that are "uncommon."

Surveys prior to habitat-disturbing activities are required for some species. Categories A and $C$ (63 species) require that site-specific surveys be conducted prior to signing NEPA decisions or decision documents for habitat-disturbing activities. Categories B, D, E, and $\mathrm{F}$ (233 species) do not require pre-disturbance surveys because surveys are not practical or species status is undetermined. 
Known sites are historic and current locations of a species. For rare species (273 species) current and future known sites are managed. Professional judgment, coupled with locally specific information, and advice from taxa specialists about the species, may be used to identify occasional sites not needed for persistence. For uncommon species (32 species), only high-priority sites need to be managed. Species do not total 296 because some species are included in more than one category.

Species inventories are conducted though "strategic surveys." Strategic surveys are landscape-scale surveys designed to collect information about a species, including its presence and habitat. They are required for all Survey and Manage species.

The Annual Species Review is the process used for annually analyzing new information about species and moving them to new categories, removing them from, or adding them to Survey and Manage. This process is based on new information about the species regarding numbers, distribution, and other factors indicating risk to persistence.

\section{Alternative 2}

Alternative 2, the Proposed Action, would amend 28 land and resource management plans within the range of the northern spotted by removing the Survey and Manage Mitigation Measure Standards and Guidelines. Conservation of rare and little known species would rely on other elements of the Northwest Forest Plan and the BLM Special Status Species Policies and the Forest Service Sensitive Species Policies. These policies are referred to collectively as the Agencies' Special Status Species Policies. The objectives of the policies are for the Agencies' to avoid actions which may contribute to the need to list a Special Status Species under the Endangered Species Act and to help maintain the diversity and viability of species on Forest Service managed lands. Species are included in these programs by the Regional Foresters and State Directors using national and regional policies.

The Agencies' reviewed the 296 Survey and Manage species to determine their eligibility for inclusion in the Agencies' existing Special Status Species Programs. Based on that review, 152 of the 296 Survey and Manage species are eligible for inclusion in one or more of the Agencies' existing Special Status Species Programs.

Existing policies that guide the activities and actions required for the Special Status Species Programs are described below. The Agencies' have the authority to update, amend, modify, change, or eliminate their policy.

Effects of proposed actions on potentially affected species are analyzed for Forest Service or BLM Sensitive and BLM Assessment (OR/WA only) species. Actions that would contribute to the need to list a Special Status Species under the Endangered Species Act or do not maintain the diversity and viability of species on Forest Service managed lands result in recommendations for removing, avoiding, or compensating this adverse effect.

Pre-project clearances are completed prior to habitat-disturbing activities to determine the presence of a species or its habitat and the effect of management actions on the species. Pre-project clearances may include, but are not limited to,

- clearance surveys;

- field clearances;

- field reconnaissance;

- inventories;

- habitat examinations;

- habitat evaluation;

- evaluation of species-habitat associations and presence of suitable or potential habitat; 
- review of existing survey records, inventories, and spatial data;

- utilization of professional research, literature, and other technology transfer sources;

- use of expertise, both internal and external, that is based on documented, substantiated professional rationale.

The following assumptions were made in the Final SEIS regarding the most likely methods for completing pre-project clearances under current Special Status Species Policies:

If pre-disturbance surveys are practical under the Survey and Manage Standards and Guidelines, then clearance surveys, field clearances, field reconnaissance, inventories, and/or habitat examinations are most likely to be used for Special Status Species.

If pre-disturbance surveys are not practical under the Survey and Manage Standards and Guidelines (most Category B and D species) or a species status is undetermined (Categories $\mathrm{E}$ and $\mathrm{F}$ species), then field surveys are not likely to occur for Special Status Species either. Instead, the other components of pre-project clearances such as habitat examinations; habitat evaluation; evaluation of specieshabitat associations and presence of suitable or potential habitat; review of existing survey records, inventories, and spatial data; or utilization of professional research, literature, and other technology transfer sources are most likely to be used.

For BLM Assessment Species (OR/WA only), pre-project clearances are required contingent on funding and personnel. When funding and personnel are not available, a review of likely habitat maps and aerial photos, and available data from other state agencies and the State Heritage Programs, is the minimum acceptable level for clearances. For species in the Bureau Assessment category, it was assumed in the Final SEIS that methods other than field surveys would be used.

Species in the BLM OR/WA tracking category are not considered a special status species for management purposes. The assumption was that pre-project clearances would not be completed and known sites would not be managed.

The assumption used in the Final SEIS for managing known sites under the Special Status Species Programs was that sites needed to prevent a listing under the Endangered Species Act would be managed. For species currently included in Survey and Manage Categories A, B, and E (which require management of all known sites), it is anticipated that only in rare cases would a site not be needed to prevent a listing. For species currently included in Survey and Manage Categories C and D (which require management of only high-priority sites), it is anticipated that loss of some sites would not contribute to a need to list. Authority to disturb special status species sites lies with the agency official who is responsible for authorizing the proposed habitat-disturbing activity.

Under Special Status Species Policies, habitat conservation assessments or conservation strategies for proposed, candidate, and sensitive species, groups of species, or specific ecosystems are used in an effort to preclude the need for listings under the Endangered Species Act. These are technical documents that describe the current state of the knowledge for the life history, habitat requirements, and management considerations for a species or group of species throughout the occupied range on lands managed by the cooperating agencies.

Under Special Status Species Policies, general inventories are conducted to learn more about a species distribution and status. General inventories are similar to Strategic Surveys. These surveys can be conducted to help develop conservation strategies. 
The Agencies update their Special Status Species lists regularly, when state heritage programs publish new rankings, or when information indicates a need.

\section{Alternative 3}

Alternative 3 would amend 28 land and resource management plans within the range of the northern spotted owl by modifying the Survey and Manage Mitigation Measure Standards and Guidelines. These modifications include: (1) removing the provisions for uncommon species; (2) eliminating the requirement to conduct pre-disturbance surveys in non-late-successional and non-old-growth forest stands; and, (3) changing the review process for excepting known sites from management and for pre-disturbance surveys in emergency situations.

For uncommon species removed from the Survey and Manage mitigation measure, known sites would be released from management constraints unless the species were included in the Agencies' Special Status Species Programs. Uncommon species included in the Special Status Species Programs would follow the assumptions listed under Alternative 2.

Exceptions for known site management and pre-disturbance surveys in emergency situations would be made by the line officer above the official responsible for the proposal instead of the Survey and Manage Intermediate Managers Group. The same criteria used under Alternative 1 (Survey and Manage Standards and Guidelines) would be used under Alternative 3 to make these determinations.

Pre-disturbance surveys would not be completed in stands that have not become latesuccessional and/ or old-growth forest for any of the species remaining in Survey and Manage.

All alternatives would continue implementation of all other elements of the Northwest Forest Plan, continue the underlying land and resource management plans for the individual administrative units, and continue relevant agency programs and policies including Special Status Species Policies which provide for the conservation goals of species. None of the Survey and Manage species are listed or petitioned for listing as threatened, endangered, or proposed for listing under the Endangered Species Act.

\section{The Decision}

Within our respective authorities, we each adopt Alternative 2 of the Final SEIS, which we had identified as the Preferred Alternative. This Decision applies to lands administered by the BLM, Forest Service, and the Coquille Tribe within the Northwest Forest Plan area as previously described. Directions for implementing this decision are set forth below.

Sections I through VIII and XII of the Survey and Manage Mitigation Measure Standards and Guidelines are removed in their entirety from the 28 land and resource management plans within the range of the northern spotted owl.

This decision does not:

1. Eliminate the portion of the Survey and Manage Mitigation Measure Standards and Guidelines that contain provisions for some non-Survey and Manage Species (certain cavity-nesting birds, some bat roosts, and the Canada lynx). The relevant sections (IX through XI) of the standards and guidelines will be retained. They are included as Appendix 1 of this Record of Decision. 
2. Affect any of the other elements of the Northwest Forest Plan, the 28 underlying land and resource management plans within the range of the northern spotted owl, as well as other relevant agency policies including Special Status Species.

\section{Authorize habitat-disturbing activities or other site-specific actions.}

4. Assign or otherwise estimate Probable Sale Quantity (PSQ) for individual administrative units. The analysis of PSQ effects in the Final SEIS has been done at the range-wide scale and does not have the precision necessary to estimate PSQ at smaller scales. The analysis provided reasonable estimates, sufficient to meet the objective of comparing differences between the alternatives. Effects at the administrative unit level will vary from this regional-level analysis based on the amount of a habitat on the individual administrative unit, the number of species ranges that fall within the unit, future detection rates, and so forth.

5. Require formal reviews or reports regarding special status species nor does it change the existing monitoring requirements contained in the Northwest Forest Plan and the land and resource management plans for each of the Forest Service and BLM administrative units within the Northwest Forest Plan area.

\section{Plans Amended}

Although this Decision continues to use the popular and inclusive title of "Northwest Forest Plan" to denote what is being amended, readers need to recognize there is no one such "Plan." The phrase denotes the April 13, 1994, amendments to existing land and resource management plans for the BLM and Forest Service within the range of the northern spotted owl relating to management of habitat for late-successional and old-growth forest related species, as listed below. Our Decision amends a portion of those previous amendments: the Survey and Manage Mitigation Measure Standards and Guidelines. The administrative units whose land and resource management plans are amended by this Decision are generally located in western Oregon and Washington (including some areas east of the Cascades) and northwestern California.

For the BLM, this Decision amends the Resource Management Plans for the Salem, Eugene, Roseburg, Medford, and Coos Bay Districts in Oregon; the Klamath Falls Resource Area of the Lakeview District, also in Oregon; and the Arcata, Redding, and Ukiah field offices in California. The King Range National Conservation Area Management Plan in the Arcata Resource Area in California is also amended. This Decision does not apply to the Headwaters area recently acquired by the BLM.

For the Forest Service, this Decision amends the National Forest Land and Resource Management Plans for the Deschutes, Gifford Pinchot, Klamath, Lassen, Mendocino, Modoc, Mt. Baker-Snoqualmie, Mt. Hood, Okanogan, Olympic, Rogue River, Siuslaw, Shasta-Trinity, Siskiyou, Six Rivers, Umpqua, Wenatchee, Willamette, and Winema National Forests.

\section{Application to Contracts, Permits, and Special Use Authorizations}

The management direction provided by this Decision applies to new contracts, permits, and special use authorizations issued after the date of this Record of Decision as required by BLM and Forest Service planning statutes and regulations. Existing contracts, permits, and special use authorizations may be adjusted in those cases where statutory or regulatory authority would allow the change. In those cases where contracts, permits, or 
special uses are not revised or amended prior to their expiration, the change will be made at the time of their renewal.

\section{Application of this Decision to Ongoing and Current Management Activities}

1. Surveys may have already been completed for individual projects. No additional survey work is required for projects that have fully complied with the current Survey and Manage Mitigation Measure Standards and Guidelines and existing Special Status Species Policies. Known sites of species formerly included in Survey and Manage that are included in the Special Status Species Programs will be managed under Special Status Species Policies. Known sites of Survey and Manage species not included in Special Status Species Programs will be released for other management uses after the effective date of this Record of Decision.

2. Surveys have been started but are not complete. Projects that are in development but have not yet fully complied with survey requirements of the Survey and Manage Mitigation Measure Standards and Guidelines may, at the discretion of the line officer responsible for the project decision, continue under those standards and guidelines or comply with the Special Status Species Policies for those Survey and Manage species that were added to the Special Status Species Programs. Former Survey and Manage species that are included in the Agencies' Special Status Species Programs will have their known sites managed under Special Status Species Policies. For Survey and Manage species not included in Special Status Species Programs, surveys will not need to be completed and known sites will be released for other management uses after the effective date of this Record of Decision.

3. Surveys have not been started. Projects that are initiated after the effective date of this Record of Decision will comply with Special Status Species Policies.

\section{Reasons for the Decision}

\section{Meeting the Purposes Identified in the Final SEIS}

The decision meets the purpose of providing for diversity of plant and animal communities in accordance with the National Forest Management Act and conserves rare and little known species that may be at risk of becoming listed under the Endangered Species Act.

The Final SEIS analyzed the effects of the alternatives on the 296 rare and little known species and 4 arthropod functional groups currently included in the Survey and Manage Mitigation Measure Standards and Guidelines. This analysis of environmental consequences to species was carefully considered in reaching our Decision.

Due to factors such as limited potential habitat, few populations on federally managed lands, potential for stochastic events, low number of individuals, limited distribution, and narrow ecological amplitude, the Final SEIS predicted that no alternative could provide sufficient habitat to support stable populations for 142 of these species (127 fungi and 15 lichens). The 1994 Northwest Forest Plan Final SEIS and the 2000 Survey and Manage Final SEIS made similar predictions for these species. Since the insufficiency of the habitat, or uncertainty of population status, is not a result of federal actions, no 
alternative or mitigation could be proposed that would change this outcome (USDA, USDI 1994a and USDA, USDI 2000a). Therefore, these effects provide little reason to choose one alternative over another.

For 79 (9 bryophytes, 14 fungi, 12 lichens, 26 mollusks, 6 vertebrates, and 12 vascular plants) of the 296 species, all of the alternatives will provide sufficient habitat to support stable populations range-wide in the Northwest Forest Plan area. Although 6 of these 79 species will have insufficient habitat to support stable populations in a portion of their Northwest Forest Plan area range under Alternative 2, the predicted outcome range-wide in the Northwest Forest Plan area does not vary between the alternatives. These effects provide little reason to choose one alternative over another.

For the 4 arthropod functional groups and 24 (6 bryophytes, 7 fungi, 11 lichens) of the 296 species, there is so little known that an outcome could not be described for the alternatives. We have so little information about the abundance, distribution, and ecology of these species, or so little information about the effects of management practices and environmental conditions including global change for some of these species, that ascribing effects of the alternatives on these species would be speculative. Therefore, there are no effects that can be described that would provide a basis to choose one alternative over another.

In summary, 245 species are not germane to the decision to choose one of the three alternatives. The alternatives under consideration here make a difference in predicted outcome for only 51 (39 fungi, 2 lichens, and 10 mollusks) of the 296 species. For these, the sufficiency of habitat to support stable populations in the Northwest Forest Plan area is predicted to be affected differently by the alternative management actions. Under Alternative 2, it is projected that there would be insufficient habitat to support stable populations in the Northwest Forest Plan area while under the No-Action Alternative there would be sufficient habitat. Under Alternative 3, it is projected that 43 of these 51 species would have sufficient habitat to support stable populations in the Northwest Forest Plan area.

While the analysis of environmental consequences for Alternative 2, which this decision adopts, predicts adverse effects to 57 species, ${ }^{2}$ we determine that Alternative 2 will still provide for diversity of plant and animal communities and conserve rare and little known species that may be at risk of becoming listed under the Endangered Species Act. Following are the reasons for our determination:

- Special Status Species Policies are forward-looking land management policies aimed at minimizing the need for listing under the Endangered Species Act. These 57 species were analyzed and determined not to meet the criteria for inclusion in these programs in all or part of their range. The list of species included in the Agencies' Special Status Species Programs is not static. The Agencies update their Special Status Species lists regularly when state heritage programs publish new rankings, or when other information indicates a need.

- All project-level activities remain subject to compliance with Federal environmental laws such as the Endangered Species Act, the National Environmental Policy Act, and the Clean Water. Act.

- Risk to species must be considered in the context of other aspects of the Northwest Forest Plan which remain in place, including:

- The Northwest Forest Plan incorporates conservation principles of maintaining: (1) connectivity across the landscape; (2) landscape heterogeneity; (3) structural complexity; and, (4) the integrity of aquatic systems.

- 86 percent of late-successional forest is reserved in the Northwest Forest Plan area.

${ }^{2}$ This includes the 51 species mentioned in the preceding paragraph, and the 6 species which have a portion of their range affected by management actions. 
- Only 2.5 - 4 percent of late-successional forest is projected to be disturbed by management in 10 years under the Northwest Forest Plan.

- Matrix Standards and Guidelines provide for retention of legacy elements of latesuccessional forest after harvest such as snags, large green trees, and down logs. There are also provisions for retaining old-growth fragments in watersheds where little remains. The Northwest Forest Plan identified these retention requirements as beneficial for many of the late-successional and old-growth forest related species.

- After 50 years, late-successional forests are projected to increase from 8 million acres to 10.7 million acres (development of late-successional forest is 2.5 times the rate of loss) on federally managed lands in the Northwest Forest Plan area.

- 80 percent of all federally managed forests in the Northwest Forest Plan area are reserved (these reserves remain the primary conservation element of the Northwest Forest Plan).

- On average, 50 percent of the federally managed land in every watershed located in the Matrix is in Riparian Reserves. ${ }^{3}$

- Although it is possible to reduce risk to species, risk remains an inherent factor of resource management.

- There is no way to avoid all risk to the continued persistence of species.

- The continued persistence of local, rare endemic species whose range is very limited is intrinsically insecure.

- Even absent any human-induced effects, the likelihood that habitat will continue to support species persistence can and does vary among species.

- The fact that the continued persistence of some species is insecure does not mean that the Agencies have failed to comply with any law or regulation (USDA, USDI 1994b).

- Any discussion of risk based on rarity and likelihood of disturbance must recognize that, for many species, only a small percentage of potential habitat has been surveyed. Reserves have not been surveyed to the same degree as Matrix and Adaptive Management Area land allocations. The Reserves were not surveyed because there has been little management-induced disturbance there. The vast majority of predisturbance surveys have been located in the Matrix and Adaptive Management Area land allocation (19 percent of the Northwest Forest Plan area), so that is where many of the known sites have been found. This does not mean that a disproportionate amount of their habitat is located in Matrix. If these species are truly closely associated with late-successional or old-growth forests (this is one of the criteria for inclusion in Survey and Manage), we can reasonably expect that the large amount of federally managed lands in Late-Successional and Riparian Reserves which provide the most amount of this type of habitat (86 percent of currently existing late-successional forests is in reserves) would also provide, at a minimum, its proportionate share of the habitat to support populations of these species.

- Within the late-successional forest ecosystems in the Northwest Forest Plan area, in order for species to persist, they would likely need some tolerance for disturbance at least at the population level. Tolerance for disturbance by species at the population level is needed because the forest ecosystems are dynamic and have historically experienced levels of disturbance. In addition, the design of the reserve system, which generally provides the most reserves in those physiographic provinces that had the most late-successional forest historically and the least natural disturbance, provides some additional assurance that late-successional and old-growth forest related species adapted to more static systems are protected.

We determine that under Alternative 2, the provisions of the Northwest Forest Plan combined with the Agencies' Special Status Species Policies provide for diversity of plant and animal communities and conserve rare and little known species that may be at risk of becoming listed under the Endangered Species Act.

\footnotetext{
${ }^{3}$ Riparian Reserves do not add up to 50 percent of land allocations overall because riparian areas in lands other than Matrix carry a higher order designation (such as Late Successional or Congressional Reserve).
} 
The decision meets the purpose of reducing the Agencies' cost, time, and effort associated with rare and little known species conservation.

Under this decision, costs will be reduced compared to Alternative 1, the No-Action Alternative, because pre-disturbance surveys will be eliminated for some species that were determined as not eligible for inclusion in the Agencies' Special Status Species Programs. Many other species included in the Agencies' Special Status Species Programs will have pre-project clearances (determining the presence or absence of species) completed in just a portion of their range because they are eligible for inclusion in the Special Status Species Programs in only a portion of their range. Since the Special Status Species policies allow the flexibility of using various methods (other than field surveys) for completing pre-project clearances, this will also reduce costs. Additionally, while some general surveys will be completed, the costs will be far less than strategic surveys under Survey and Manage. Finally, the current Survey and Manage program is a highly centralized program with mandatory processes and procedures. The Agencies' Special Status Species Programs are less centralized and allow more flexibility in processes and procedures. This will result in program management costs far lower than under the other alternatives. Under Alternative 2, the Agencies' short-term (1-5 years) annual costs are projected at $\$ 10$ million. This will result in a short-term cost savings of $\$ 15.9$ million per year compared to Alternative 1. The Agencies' long-term (6-10 years) annual costs are projected at $\$ 9.5$ million. This will result in a long-term cost savings of $\$ 7.3$ million per year compared to Alternative 1. Under Alternative 3, the Agencies' short-term annual costs are projected at $\$ 11.8$ million and the long-term annual costs are projected at $\$ 10.3$ million. Both short-term and long-term cost savings under this decision (adoption of Alternative 2) will be greater than those of the other alternatives.

Additionally, annual personal income related to forestry employment would be much greater under Alternative 2 compared to Alternatives 1 or 3 . Under Alternative 2 there would be a projected increase in annual personal earnings of $\$ 13.1$ million per year compared to Alternative 1 and a projected increase of $\$ 2.1$ million per year compared to Alternative 3.

The decision meets the purpose of restoring the Agencies' ability to achieve Northwest Forest Plan resource management goals and predicted timber outputs.

For timber harvest, the 1994 Northwest Forest Plan Final SEIS included Probable Sale Quantity (PSQ) estimates for each BLM District and National Forest that reflected a 6 million board foot (MMBF) reduction in annual harvest due to implementation of the Survey and Manage Mitigation Measure Standards and Guidelines. This reduction was based on sites known at that time. Future effects were not estimated in part because the species were so little known that there was little information upon which to estimate effects, and little reason to believe it would be large. Hence, the 1994 Northwest Forest Plan Final SEIS described Survey and Manage as "add[ing] uncertainty" to harvest projections. Because the Agencies have found so many more sites than anticipated for some species, the No-Action Alternative would reduce PSQ by approximately $105 \mathrm{MMBF}$, from the current PSQ level of $805 \mathrm{MMBF}$. Under Alternative 2, it is projected that the PSQ would be reduced by $35 \mathrm{MMBF}$ from the current PSQ level of $805 \mathrm{MMBF}$. Under Alternative 3, it is projected that the PSQ would be reduced by $45 \mathrm{MMBF}$. The decision which adopts Alternative 2 best restores the Agencies' ability to achieve the level of predicted timber outputs under the Northwest Forest Plan.

In determining the effects to timber harvest, it was estimated that 15 percent of latesuccessional forest in the Matrix and Adaptive Management Area land allocation is currently encumbered by species site management. Survey and Manage applies to all land allocations so the various impacts to resource management activities in latesuccessional forests would also occur in areas other than the Matrix land allocation. Extrapolating from the projections in the timber harvest section, we expect occupied 
species sites of Survey and Manage species under Alternative 1 to affect, and thus encumber, resource management projects including those designed to improve forest health to the same degree (up to 15 percent) in late-successional forests in all land allocations. This decision reduces this effect to about 5 percent of late-successional forests.

By adopting Alternative 2, this decision is projected to increase the annual acres available for hazardous fuel treatments to nearly 159,000, an increase of approximately 9,000 acres compared to Alternative 1, the No-Action Alternative. The part of fuel treatment cost associated with species management are projected to be $\$ 37$ per acre, a decrease of $\$ 57$ compared with Alternative 1.

Under Alternative 3, the annual acres available for hazardous fuel treatments are projected to be 157,000 , a decrease of approximately 2,000 acres compared to Alternative 2. The part of fuel treatment cost associated with species management are projected at $\$ 29$ per acre, a decrease of $\$ 8$ compared with Alternative 2 . This decrease in cost is due to a provision of Alternative 3 that exempts management activities in non-late-successional stands from survey.

Although the fuel treatment cost per acre is less under Alternative 3, there would be more acres available for hazardous fuel treatments under Alternative 2. This would result in increased ability to implement projects designed to improve forest health including more efficient implementation of the National Fire Plan under Alternative 2.

\section{Summary of the Reasons for the Decision}

The underlying needs to which the Agencies are responding are healthy forest ecosystems and a sustainable supply of timber and other forest products, to the extent these are frustrated by the Survey and Manage Mitigation Measure Standards and Guidelines. The Northwest Forest Plan goals have their origin in the Forest Service and BLM multiple-use missions.

For the BLM, this is based in the Federal Land Policy and Management Act of 1976 (FLPMA) where the term "multiple use" management is defined as "... management of the public lands and their various resource values so that they are utilized in the combination that will best meet the present and future needs of the American people." FLPMA requires that the public lands be managed in a manner which provides for ". . . a combination of balanced and diverse resource uses that takes into account the longterm needs of future generations for renewable and nonrenewable resources, including, but not limited to, recreation, range, timber, minerals, watershed, wildlife and fish, and natural scenic, scientific and historical values."

For the Forest Service, in the Multiple-Use Sustained-Yield Act of 1960, Congress directed the Forest Service to manage national forests for "outdoor recreation, range, timber, watershed, and wildlife and fish resources and the sustained yield of the shared products and services obtained from renewable resources." Multiple use means managing resources under the best combination of uses to benefit the American people while ensuring the productivity of the land and protecting the quality of the environment.

The Survey and Manage Mitigation Measure Standards and Guidelines represent an overly cautious approach, particularly when we consider that none of these species are listed or petitioned for listing under the Endangered Species Act. Continuing to spend millions of dollars on this effort which is preventing the Agencies from achieving their multiple-use missions while existing policies already provide for species conservation is ill-advised. 
The Northwest Forest Plan was an attempt to strike a balance between conserving ecosystems upon which species depend and providing raw materials that are needed to sustain the health and economic well-being of communities. The Northwest Forest Plan balanced these two sometimes conflicting purposes by maintaining the late-successional, old-growth forest ecosystem while also providing a predictable and sustainable supply of timber, recreational opportunities, and other resources at the highest possible level. At the time, it was concluded that the occurrences of these species would be rare and effects on lands available for harvest would be minimal (USDA, USDI 2000a). Since that time, we have come to understand that the effects were greatly underestimated. The effects of this mitigation measure on our ability to maintain and restore healthy ecosystems as well as provide a sustainable and predictable timber supply have been considerable. There is much that remains unknown about many of the Survey and Manage Species. In fact, no new sites have been discovered for more than 100 species despite the fact that surveys have been underway for more than 5 years and tens of millions of dollars have been spent on them. Due to the rarity of these species, it is unknown if sufficient information will ever be discovered.

Our decision to adopt Alternative 2 will best restore our ability to accomplish the dual goals of the Northwest Forest Plan. Specifically, it best achieves the purposes set forth in the Final SEIS which include providing for species diversity and conservation, reducing costs and effort, and restoring our ability to implement Northwest Forest Plan resource management goals and predicted timber outputs. Alternative 2 provides for species diversity and conservation through the Northwest Forest Plan and the Agencies' Special Status Species Policies, the largest short and long-term cost reduction, the best opportunity for accomplishing resource management projects to improve forest health, and best improves the Agencies' ability to achieve the level of predicted timber outputs under the Northwest Forest Plan compared to the other alternatives.

\section{Other Alternatives Considered in Detail and Reasons They Were Not Selected}

\section{Alternative 1, No-Action}

Alternative 1, the No-Action Alternative, would have continued implementation of the Survey and Manage Mitigation Measure Standards and Guidelines, the underlying land and resource management plans, and relevant agency policies. Although this alternative assumed the continuing implementation of the Agencies' Special Status Species policies, it is important to note that less than 10 percent of the 296 Survey and Manage species are currently included as "sensitive" under one or more of these programs (mostly dating from before the Northwest Forest Plan). Since adoption of the Northwest Forest Plan, the Agencies have generally chosen to not include Survey and Manage species in their Special Status Species Programs because the Survey and Manage Mitigation Measure Standards and Guidelines accomplish the Special Status Species policy objectives.

We reject the No-Action Alternative because, while it meets the purpose of providing for diversity of plant and animal communities and conserving rare and little known species that may be at risk of becoming listed under the Endangered Species Act, it does not meet the other purposes. Specifically, it does not reduce the costs, time, and effort associated with rare and little known species conservation. It would also continue to frustrate the Agencies' ability to achieve Northwest Forest Plan resource management goals and predicted timber outputs. 


\section{Alternative 3, Modified Survey and Manage}

Alternative 3 would have amended 28 land and resource management plans within the range of the northern spotted owl by modifying the Survey and Manage Mitigation Measure Standards and Guidelines. Modifications would have included: (1) removing the uncommon species category and all requirements pertaining to that category; (2) eliminating the requirement to conduct pre-disturbance surveys in non-late-successional and non-old-growth forest stands; and, (3) changing the review requirements for excepting known sites from management and for excepting pre-disturbance survey requirements in emergency situations.

Twenty-eight Survey and Manage species plus 4 arthropod functional groups are currently categorized as uncommon. However, only 24 species would have been removed entirely from the Survey and Manage Mitigation Measure Standards and Guidelines because 4 of these species have part of their range in the rare species category. Since these 28 species were potentially eligible for the Agencies' Special Status Species Programs, the Agencies reviewed the species and determined that 14 of the 28 species were eligible for inclusion.

If Alternative 3 had been selected, 272 of the Survey and Manage species would have continued to be managed under that program. Fourteen of the Survey and Manage species would have been managed under the Agencies' Special Status Species Programs. The remaining species and four arthropod functional groups would have received no species-specific management.

We reject Alternative 3 because it does not best achieve our purposes. Specifically, Alternative 3 does not reduce short or long-term costs, increase our ability to implement resource management projects to improve forest health, nor improve the Agencies' ability to achieve the predicted timber output under the Northwest Forest Plan as well as Alternative 2.

\section{Mitigation of Adverse Environmental Consequences Associated with this Decision}

Mitigation measures avoid, rectify, reduce, or eliminate potentially adverse environmental impacts of management activities. Council on Environmental Quality (CEQ) regulations require agencies to include appropriate mitigation measures not already included in the proposed action or alternatives (40 CFR 1502.14(f)) and include a discussion of means to mitigate adverse environmental impacts (40 CFR 1502.16(h)). Pages 54 and 59-66 of the Final SEIS contain a detailed description of potential mitigation measures that could be used to mitigate the adverse effects to species that could occur under Alternative 2. They generally consist of completing pre-project clearances and managing known sites. We have considered these potential mitigation measures as described below.

Due to factors such as limited potential habitat, few populations on federally managed lands, potential for stochastic events, low number of individuals, limited distribution, and narrow ecological amplitude, the Final SEIS predicted that no alternative could provide sufficient habitat to support stable populations for 142 species (127 fungi and 15 lichens). The 1994 Northwest Forest Plan Final SEIS and the 2000 Survey and Manage Final SEIS made similar predictions for these species. We are not selecting mitigation for these species even though it could reduce risk to them because the predicted outcome of insufficient habitat is not a result of federal actions and no alternative or mitigation could be proposed that would change that outcome (USDA, USDI 1994a and USDA, USDI 2000a). 
For the 4 arthropod functional groups and 24 ( 6 bryophytes, 7 fungi, and 11 lichens) species, there is so little known about these species that an outcome could not be described for the alternatives. We are not selecting mitigation for these species because we have so little information about the abundance, distribution, and ecology of these species, or even for some, the effects of management practices and environmental conditions such as global change on these species, that ascribing benefits to species through the implementation of mitigation measures would be speculative.

For 57 species, the analysis of environmental consequences indicates that removing the Survey and Manage requirements for management of species sites and/or predisturbance surveys under Alternative 2 increases the risk that there could be insufficient habitat to support stable populations in all or a portion of their Northwest Forest Plan area range. In these cases, mitigation under Alternative 2 was identified that could eliminate this potential adverse environmental effect. Mitigation would consist of completing pre-project clearances (determining the presence of species prior to habitat disturbing activities) and/or managing known sites. Compared to Alternative 2 without mitigation, these measures would increase annual species management costs by $\$ 600,000$ per year, result in an estimated $\$ 200,000$ losś in annual personal income (due to reduction of forestry-related jobs), reduce annual hazardous fuel treatments by 200 acres and increase costs for treatment by $\$ 3$ an acre. In addition, mitigation would reduce timber harvest by 2 million board feet per year.

We are not selecting this mitigation for two reasons. First, Alternative 2 as it stands alone provides for diversity of species. As described in detail in the "Reasons for the Decision" section of this document, we believe the Northwest Forest Plan and the Agencies' Special Status Species Policies provide an adequate level of protection for species. Viewed in the overall context of the Northwest Forest Plan, we believe the increased risk is small. Second, when these mitigation measures are added to Alternative 2, that alternative would not sufficiently reduce cost, time, and effort associated with rare and little known species management and would continue to frustrate the Agencies' ability to achieve resource goals and predicted timber outputs that were established under the Northwest Forest Plan.

\section{Findings}

Except as otherwise discussed below, this decision builds on the findings of compliance with applicable laws found in the April 13, 1994, Record of Decision for the Amendments to Forest Service and Bureau of Land Management Planning Documents Within the Range of the Northern Spotted Owl, which this decision amends.

\section{National Environmental Policy Act (NEPA)}

The NEPA requires that Federal agencies prepare detailed statements on proposed actions that significantly affect the quality of the human environment. The BLM and Forest Service have both integrated NEPA reviews with their land management planning process. For each agency, an environmental impact statement (EIS) accompanies its land and resource management plans. The BLM and Forest Service will tier to the Final SEIS with NEPA documents on specific activities.

The Final SEIS and referenced documents compiled and considered all new relevant information. These data build upon information already compiled in the 1994 Northwest Forest Plan Final SEIS, the 2000 Survey and Manage Final SEIS, and the Annual Species Reviews. All the available information about these species was considered 
and a thorough analysis of the potential environmental effects associated with each of the alternatives and the differences between them was completed. See also the section entitled "Endangered Species Act," below, for a discussion addressing why supplementation of the Final SEIS is not necessary.

There has also been extensive opportunity for public involvement in the NEPA process. Scoping letters were sent to 3,300 individuals. The Draft SEIS was sent out to more than 4,000 persons, elected officials, agencies, and groups. The mailing list included those responding to the Notice of Intent published in the Federal Register or the scoping letter, and those responding to an interagency Environmental Impact Statement on Survey and Manage in 2000. A 90-day comment period was provided to comment on the Draft SEIS, and more than 5,000 comments were received. The Agencies used these comments to improve the Final SEIS analysis. The Agencies responded to the substantive comments, as well as others, raised in these comments. These responses are included in Appendix 6 of the Final SEIS

Moreover, we find that the process also complied with the requirements set forth in the regulations that the CEQ has promulgated to implement NEPA:

1. An environmental impact statement must rigorously explore and objectively evaluate all reasonable alternatives. The range of alternatives is limited by the requirement to fulfill the Purpose and Need to which the Agencies are responding in proposing the action. Among potential alternatives considered were various strategies proposed by the public during the scoping process, as well as some strategies proposed by Agency staff. Many of these alternatives were eliminated from detailed study in attempts to find reasonable alternatives that would fulfill the Need and Purposes for the Proposed Action. The Need, as described in Chapter 1 of the Final SEIS (p. 5), is the need for "healthy forest ecosystems and a sustainable supply of timber and other forest products, to the extent these are frustrated by the Survey and Manage Standards and Guidelines." This includes purposes to conserve rare and little known species, reduce costs, and improve the Agencies' ability to achieve the Northwest Forest Plan resource management goals and predicted timber outputs. The Purpose and Need substantially limited the range of reasonable alternatives available for analysis and provided a relatively narrow scope for this action.

2. The Final SEIS considered the cumulative effects of the proposed action and all other past, present, and reasonably foreseeable future actions within the planning area. Although the management of non-federal lands are outside the scope of the Final SEIS, effects from their management have been considered in the Final SEIS to a degree appropriate for a programmatic NEPA document and the nature of the species involved.

3. There is a lack of information regarding many of the species analyzed in the Final SEIS. For 24 species and 4 arthropod functional groups, there was not sufficient information to predict environmental consequences. The "Incomplete and Unavailable Information" section of the Final SEIS (pp. 108-109) discusses this lack of information. The rationale and basis for the decision, including the species for which there was not sufficient information, is discussed above under "Reasons for the Decision." None of the incomplete or unavailable information was deemed essential for a reasoned choice among the alternatives because the Final SEIS analysis clearly establishes the relationships between the alternatives in comparative form. It describes the levels of risk and the relative benefits of each of the alternatives, thus sharply defining the issues and providing a clear basis for a choice by the responsible officials.

This decision does not authorize timber sales or any other specific activity on federally managed lands. Compliance with NEPA, the Endangered Species Act, and other environmental laws is required before decisions are made to offer timber sales or conduct 
other land management activities. There are also opportunities for administrative appeals of site-specific decisions. This Record of Decision complies with 40 CFR 1505.2(b) and (c).

\section{National Forest Management Act (NFMA)}

The NFMA is an amendment to the Forest and Rangeland Renewable Resources Planning Act. In NFMA, Congress established a comprehensive notice and comment process for adopting, amending, and revising land and resource management plans (forest plans) for units of the National Forest System. This decision amends 19 forest plans in accordance with the National Forest System Land and Resource Planning regulations promulgated in 1982 (36 CFR part 219 (1999)).

Our decision involves two key elements of the NFMA and related regulations. The NFMA requires the Secretary of Agriculture to promulgate regulations to guide Forest Service planning. One of the statutory requirements of this law is to "provide for diversity of plant and animal communities based on the suitability and capability of the specific land area in order to meet overall multiple-use objectives, and within the multiple-use objectives of a land management plan...." (16 U.S.C. 1604(g)(3)(B).) The Secretary of Agriculture promulgated NMFA implementing regulations in 1982 at 36 CFR 219 that provide for species viability and diversity of plant and animal communities.

\section{Viability Provision}

Sec. 219.19 Fish and wildlife resource. Fish and wildlife habitat shall be managed to maintain viable populations of existing native and desired non-native vertebrate species in the planning area. For planning purposes, a viable population shall be regarded as one which has the estimated numbers and distribution of reproductive individuals to insure its continued existence is well distributed in the planning area. In order to insure that viable populations will be maintained, habitat must be provided to support, at least, a minimum number of reproductive individuals and that habitat must be well distributed so that those individuals can interact with others in the planning area.

The 1994 Record of Decision for the Northwest Forest Plan stated that the viability provision does not require species-specific assessments. Rather, in accord with the theme of ecosystem management, a decision maker may place reasonable reliance upon assessments of: (1) species with habitat needs that are roughly the same; (2) a group of species generally thought to perform the same or similar ecosystem functions; and/or (3) the continued integrity and function of ecosystem(s) in which a species is found. Flexibility in selecting methodology is especially appropriate in this context, given the expertise and knowledge of local forest officials concerning the lands they manage, the variety of complex issues involved, and the often limited resources available.

By its own terms, the viability provision of the Forest Service Planning Regulations applies only to vertebrate species. We find that this decision satisfies the viability provision of the NFMA implementing regulations because the Final SEIS analysis indicates that under Alternative 2, as adopted by this decision, no vertebrate species would have "insufficient habitat" that does not already have such an outcome under the No-Action Alternative. Several species (red tree vole and Siskiyou salamander) have "insufficient habitat to support stable populations in a portion of the Northwest Forest Plan area." These two species are included in the Agencies' Special Status Species Programs in these portions of the Northwest Plan area. The outcome is due to factors beyond the Agencies' control such as limited potential habitat, few populations on federally managed lands, potential for stochastic events, low number of individuals, 
limited distribution, and narrow ecological amplitude. Since the insufficient habitat is not a result of federal actions, no alternative could be proposed that would change this outcome (USDA, USDI 1994a and USDA, USDI 2000a).

\section{Diversity Provision}

Sec. 219.26 Diversity. Forest planning shall provide for diversity of plant and animal communities and tree species consistent with the overall multiple-use objectives of the planning area. Such diversity shall be considered throughout the planning process. Inventories shall include quantitative data making possible the evaluation of diversity in terms of its prior and present condition. For each planning alternative, the interdisciplinary team shall consider how diversity will be affected by various mixes of resource outputs and uses, including proposed management practices. (Refer to Sec. 219.27(g)).

Sec. 219.27(g) Diversity. Management prescriptions, where appropriate and to the extent practicable, shall preserve and enhance the diversity of plant and animal communities, including endemic and desirable naturalized plant and animal species, so that it is at least as great as that which would be expected in a natural forest and the diversity of tree species similar to that existing in the planning area. Reductions in diversity of plant and animal communities and tree species from that which would be expected in a natural forest, or from that similar to the existing diversity in the planning area, may be prescribed only where needed to meet overall multiple-use objectives.

Because of the enormous complexity and dynamic nature of the ecosystems managed under the NFMA, there is no specific or precise standard or technique for satisfying these requirements, as recognized by the scientific community and many courts. The Committee of Scientists (May 4,1979) that provided scientific advice to the Forest Service on the crafting of the initial NFMA regulations stated that "it is impossible to write specific regulations to 'provide for diversity'..." and "[t]here remains a great deal of room for honest debate on the translation of policy into management planning requirements and into management programs." (44 Fed. Reg. 26,600 and 26,608.)

Courts have recognized that NFMA does not create any concrete standard for diversity. In fact, the U.S. District Court in Seattle Audubon Society v. Moseley, 798 F. Supp 1484 (W.D. Wash. 1992), stated that the Forest Service must use common sense and apply its fish and wildlife expertise in implementing these requirements. The court also stated that, "The Forest Service argues that it should not be required to conduct a viability analysis as to every species. There is no such requirement. As in any administrative field, common sense and agency expertise must be applied." Id. at 1490. In its affirmation of the decision to adopt the Northwest Forest Plan, the same court again made it clear that providing for species diversity on the forests was to be done in the context of the overall multiple-use objectives of NFMA. See Seattle Audubon Society v. Lyons, 871 F. Supp 291, at 1315-1316 (W.D. Wash. 1994). On appeal, the Ninth Circuit Court described NFMA as inherently flexible on this point, and based on the fact that the defendants had not overlooked any relevant factors or made any clear errors held that the application by the Agencies of the viability regulation in the Northwest Forest Plan was reasonable. See Seattle Audubon Society v. Moseley, 80 F.3d 1401, at 1404-1405 (Ninth Cir. 1996).

Relevant factors analyzed in the Final SEIS include the life history of species, the current amount and distribution of habitat, the amount and distribution of species' ranges within the planning area, and other reasonably foreseeable protective measures. The effects discussions in the Final SEIS address each of the 296 species and 4 arthropod functional groups covered by the Survey and Manage Mitigation Measure Standards and 
Guidelines. The analysis of environmental consequences predicts, to the extent available information will allow, likely outcomes regarding the sufficiency of habitat for these species. Although absolute certainty is not possible, the Final SEIS uses a standard of reasonable certainty to predict outcomes.

The best information results in projecting an outcome of "insufficient habitat to support stable populations in the Northwest Forest Plan area" for 142 species under each alternative. No alternative within the scope of the Final SEIS could change this projected outcome. For another 24 species and 4 arthropod functional groups, there is insufficient information to predict an outcome.

Although our decision to adopt Alternative 2 increases the risk that there could be insufficient habitat to support stable populations in all or a portion of their Northwest Forest Plan area range for 57 species, this does not mean that the Agencies have failed to comply with any law or regulation. Within the overall context of the Northwest Forest Plan, we believe the increased risk is small. We find that the provisions of the Northwest Forest Plan and the Agencies' Special Status Species Policies will provide for diversity of plant and animal communities and conserve rare and little known species that may be at risk of becoming listed under the Endangered Species Act. Refer to the "Reasons of the Decision" section in this Record of Decision for a detailed description of the reasons for our determination. We determined that, to the extent practicable, we are providing for diversity of plant and animal communities while remaining consistent with multiple-use management through the Northwest Forest Plan and the Agencies' Special Status Species Policies. Although there is some risk that reduction in diversity of plant and animal communities from the existing diversity in the planning area could occur, it is warranted in order that we remain consistent with our overall multiple-use objective.

We also find, based on the Biological Evaluation (see Appendix 5 of the Final SEIS) and earlier findings on which this decision relies, that our decision will not jeopardize the continued existence of any species listed under the Endangered Species Act.

The Forest Service intends to issue amended National Forest Management Act implementing regulations in the near future. It is not anticipated that the new regulations will affect this decision.

\section{Forest Service Land and Resource Management Plan Amendments}

Pursuant to 36 CFR 219.25(b) (2003), the Forest Service elected to initiate these plan amendments under the 1982 planning regulations. Forest plan amendments are used to keep the management direction for National Forests up-to-date. The amendment process includes programmatic compliance with NEPA and other environmental laws. If an amendment to a Forest Plan results in "a significant change in the plan," NFMA and the 1982 implementing regulations require that the amendment process follow the procedures used in the initial development of the plan. If the proposed change in the plan is not significant, public notification and completion of the NEPA procedures are still required (36 CFR 219.10(f)), as was completed for this decision.

"Significant" change in a forest plan is determined by different criteria than those used in evaluating significance in the NEPA process. For the NFMA requirement, the Forest Service Manual (FSM 1922.51 and .52) provides specific direction. As discussed in more detail in the Final SEIS (pp. 23-24), changes to the forest plan that are not significant can result from: (1) actions that do not significantly alter the multiple-use goals and objectives for the long-term land and resource management; (2) adjustments of management area boundaries or management prescriptions resulting from further on-site analysis when the adjustments do not cause significant changes in the multipleuse goals and objectives for long-term land and resource management; (3) minor changes 
in standards and guidelines; and, (4) opportunities for additional management practices that will contribute to achievement of the management prescription. On the other hand, examples of changes that are indicative of circumstances that may cause a significant change to a forest plan include: (1) changes that would significantly alter the long-term relationship between levels of multiple-use goods and services originally projected (36 CFR 219.10(e)); and, (2) changes that may have an important effect on the entire forest plan or affect land and resources throughout a large portion of the planning area during the planning period.

The changes resulting from this decision are not significant. Our decision eliminates a mitigation measure; it will not significantly change any key elements of the underlying Northwest Forest Plan strategy or standards and guidelines, and would help achieve (and not significantly alter) the relationship between the levels of multiple-use goods and services originally projected. A detailed description of why the changes are not significant can be found in the Final SEIS on pages 23-24.

We conclude that the changes affected by this decision are not significant in the context of the 1982 Forest Service Planning Regulations, and that the requirements for amending National Forest land and resource management plans have been met.

\section{Endangered Species Act}

Section 7(a)(2) of the Endangered Species Act requires that Federal agencies consult with the U.S. Fish and Wildlife Service and NOAA Fisheries, as appropriate, to ensure that their actions do not jeopardize the continued existence of species listed as threatened or endangered under the Endangered Species Act, or destroy or adversely modify their critical habitat. The Agencies completed a Biological Evaluation (included as Appendix 5 of the Final SEIS) and a Biological Assessment derived from the Biological Evaluation that determined that the preferred alternative, Alternative 2, would not affect any species listed or proposed for listing as threatened or endangered except for the northern spotted owl. The Agencies made a determination of "may affect, not likely to adversely affect" for the northern spotted owl and its critical habitat. As explained in the Biological Assessment (pp. 6 and 18) and the Final SEIS (p. 210), the Agencies determined that Alternative 2 would result in "negligible and minor losses" in the amount of spotted owl habitat and, therefore, would have "no or very minimal adverse effects" on the species or its critical habitat.

In response to the Biological Assessment and the Agencies' determination of "may affect, not likely to adversely affect," the U.S. Fish and Wildlife Service prepared a Biological Opinion on March 15, 2004, on the effects of Alternative 2 on the northern spotted owl and its critical habitat. In the Biological Opinion, the U.S. Fish and Wildlife Service did not concur with the Agencies' not likely to adversely affect determination, but concluded nevertheless that the proposed action would not jeopardize the continued existence of the northern spotted owl or destroy or adversely modify its critical habitat. The U.S. Fish and Wildlife Service found that the "biological significance" of any potential adverse effects of Alternative 2 on the spotted owl or its critical habitat would be "minimal" (Biological Opinion, pp. 18 and 20). Thus, both the Agencies and the U.S. Fish and Wildlife Service similarly concluded that Alternative 2 would have, at most, "minimal" adverse effects on the northern spotted owl or its critical habitat.

Moreover, the basis for both the Agencies' and the U.S. Fish and Wildlife Service's conclusions was essentially the same. The Agencies determined that none of the alternatives analyzed in the Final SEIS (p. 210) would "affect the original basis for the assessment or the conclusion of the effects to spotted owls as presented in the Northwest Plan Final SEIS" and that areas for owl breeding clusters and dispersal would continue to be provided. Further, they determined that due to their "small size and dispersed array," 
the Survey and Manage species known sites that "would be returned to underlying land allocations and [become] potentially available for timber harvest would not lower the amount of habitat or change the distribution of habitat originally expected to be available to spotted owls" (Final SEIS, pp. 210-11 and Biological Assessment, p. 5).

Similarly, the U.S. Fish and Wildlife Service found possible effects of the proposed action to the owl and its critical habitat minimal, "[g]iven the relatively small magnitude of federally managed Late Successional Old Growth habitat potentially affected by the proposed action, and the scattered distribution of Survey and Manage sites throughout the NWFP area ..." (Biological Opinion, pp. 19-20). The U.S. Fish and Wildlife Service also recognized, as did the Agencies, that the proposed action does not in any way affect the protections for the owl and its habitat provided in the Northwest Forest Plan, "the proposed action is not likely to diminish the function of the conservation program established under the NWFP to protect the owl and its habitat on Federal lands within its range" (Biological Opinion, p. 19). The consultation in 1994 on the government's conservation plan for the northern spotted owl, otherwise known as the Northwest Forest Plan, did not ascribe any quantifiable benefit to the owl from the Survey and Manage mitigation measure. In that 1994 Biological Opinion (p. 20), the U.S. Fish and Wildlife Service found that the Riparian Reserves interspersed throughout the Matrix land allocation, the green tree retention requirements, the 15 percent late-successional requirement, and other provisions would provide sufficiently for the connectivity required for dispersal between Late-Successional Reserves without attributing any contribution to such habitat from the Survey and Manage mitigation measure.

Finally, the Agencies and the U.S. Fish and Wildlife Service recognize that the decision to remove the Survey and Manage Standards and Guidelines does not alter the requirement for project-level consultations and that the proposed action would not "authorize timber sales or other habitat-disturbing activities." (See Final SEIS, p. 219 and Biological Opinion, pp. 18, 20, and 21). Thus, before any of the formerly protected areas under the Survey and Manage mitigation measure would be disturbed, further project-level analysis and decision-making would take place, during which the Agencies would consult on any proposed actions which are likely to adversely affect any listed species.

Consequently, we believe that the fact that the Agencies and the U.S. Fish and Wildlife Service reached different conclusions concerning whether the proposed action is likely to adversely affect the northern spotted owl or adversely modify its critical habitat is not significant.

In addition, the fact that the Agencies and the U.S. Fish and Wildlife Service reached different conclusions concerning whether the proposed action is likely to adversely affect the northern spotted owl or its critical habitat does not constitute significant new circumstances or information relevant to environmental concerns that would require the Agencies to supplement the Final SEIS in accordance with CEQ regulations. As noted above, the conclusions of the Agencies and the U.S. Fish and Wildlife Service are essentially indistinguishable-i.e., that the impacts of the proposed action would be so small and scattered that they would result in only minimal adverse effects on the spotted owl and its critical habitat. We believe that the difference in views (not likely to adversely affect vs. adverse effects but minimal and not likely to jeopardize) does not rise to the CEQ regulatory threshold for requiring re-circulation of a draft SEIS for additional public comment and issuance of a new Final SEIS. Furthermore, the U.S. Fish and Wildlife Service's Biological Opinion does not describe any impacts or possible mitigation which significantly differs from the information or mitigation considered in the Final SEIS or the other NEPA documents to which it is tiered. 


\section{Federal Land Policy and Management Act}

The Federal Land Policy and Management Act (FLPMA) and its implementing regulations, provide land use planning authority to the Secretary of the Interior. The most pertinent section to the present decision is the regulation at 43 CFR 1610.5-5 concerning amendments to BLM resource management plans, which shall be initiated by the need to consider new evaluation findings or new data, among other reasons. In the event a decision is made to prepare an environmental impact statement, the amending process follows the same procedure required for the preparation and approval of the resource management plan, but consideration shall be limited to only the portion of the plan being amended. These procedures have been followed in preparing this decision to amend the 1994 Record of Decision which amends the resource management plans of the BLM. The Final SEIS Governor's Consistency Review for Oregon and California (no Washington BLM lands are included in this decision) was initiated on December 23, 2003.

The principles of multiple use and sustained yield have been applied in the development of this decision. The opportunity for utilization of resources from the lands within species sites managed under the Agencies' Special Status Species Policies is in accordance with the principles of multiple use and sustained yield (see 43 U.S.C. 1712(c)(1)). Because timber use is not totally eliminated, this decision will not be subject to the reporting requirement in 43 U.S.C. $1712(\mathrm{e})(2)$.

\section{Oregon and California Railroad and Coos Bay Wagon Road Grant Lands Act (O\&C Act)}

Conformance with the O\&C Act is discussed in the 1994 Record of Decision for the Northwest Forest Plan upon which these findings build. The 1994 Record of Decision for the Northwest Forest Plan found that the Northwest Forest Plan was consistent with the O\&C Act. It identifies the appropriateness of the system of reserves and other elements of the Northwest Forest Plan which, among other things, precluded the need for many species to be included in Survey and Manage Mitigation Measure and will also preclude inclusion of many species in the Agencies' Special Status Species Programs.

\section{Protection of Tribal Treaty Rights and Trust Resources}

American Indian treaty rights and trust resources will be protected under this decision. This decision has effects on tribal treaty rights and trust resources similar to the Northwest Forest Plan. This decision influences management of the Coquille Forest. These lands are part of the Coquille Indian Reservation, and are held in trust by the United States. An Act of Congress in 1996 transferred ownership of about 5,400 acres of federal land within the Northwest Forest Plan area to the Coquille Indian Tribe. The Act required that the Coquille Forest be managed subject to the same direction as adjacent or nearby federal lands. The Coquille Indian Tribe did not provide comment during the public comment period for the Draft SEIS.

\section{Review by the Regional Interagency Executive Committee (RIEC)}

The Northwest Forest Plan Record of Decision at page E-18 requires the preparation of amendments to the Northwest Forest Plan be coordinated with, and reviewed by, the RIEC. The purpose of the review is to "... assure consistency with the objectives of these [Northwest Forest Plan] standards and guidelines." The record shows the RIEC has been 
involved, and concurred with the Notice of Intent, the Preferred Alternative in both the Draft and Final SEIS, and some agencies also provided specific comments. On January 23, 2004, a subcommittee of Agency executives authorized by the RIEC reviewed the alternative selected in this Record of Decision.

\section{Valid Existing Rights}

This decision does not repeal valid existing rights on public lands. Valid existing rights are those rights or claims to rights that take precedence over the actions contained in this plan. Valid existing rights may be held by other Federal, State, or local government agencies or by private individuals or companies. Valid existing rights may pertain to mining claims, mineral or energy easements, rights-of-way, reciprocal rights-of-way, leases, agreements, permits, and water rights.

\section{Identification of the Environmentally Preferable Alternative}

CEQ regulations require that the Record of Decision specify "the alternative or alternatives which were considered to be environmentally preferable" (40 CFR 1505.2(b)). CEQ's "Forty Most Asked Questions" document (46 Federal Register 18026, March 23, 1981) clarifies that "The environmentally preferable alternative is the alternative that will promote the national environmental policy as expressed in NEPA's Section 101. Ordinarily, this means the alternative that causes the least damage to the biological and physical environment; it also means the alternative that best protects, preserves, and enhances historic, cultural, and natural resources." NEPA's Section 101 calls for Federal agencies to make decisions to achieve "conditions under which man and nature and exist in productive harmony and fulfill the social, economic, and other requirements of present and future generations of Americans." It also calls for Federal agencies to "3. attain the widest range of beneficial uses of the environment without degradation, risk to health or safety, or other undesirable and unintended consequences; . . . 5. achieve a balance between population and resource use which will permit high standards of living and a wide sharing of life's amenities; and 6. enhance the quality of renewable resources and approach the maximum attainable recycling of depletable resources." See National Environmental Policy Act of 1969, Sec. 101.

It would be difficult to support Alternative 1 as meeting the criteria of "environmentally preferred" using the approach suggested by CEQ. One of the major reasons that necessitates a change to the existing situation is that the Survey and Manage Mitigation Measure Standards and Guidelines interfere with the Agencies' ability to implement hazardous fuel treatment projects as well as the other resource management projects needed to implement the forest health goals identified in the Northwest Forest Plan. The existing situation is the one created by Alternative 1 ; therefore, this alternative is not environmentally preferred.

Alternatives 2 and 3 are both environmentally preferred over Alternative 1 for the following reasons:

1. Alternatives 2 and 3 would both increase the Agencies' ability to accomplish resource management projects to improve forest health while continuing to provide for diversity of plant and animal communities and conserving rare and little known species that may be at risk of becoming listed under the Endangered Species Act. Occupied sites of Survey and Manage species under Alternative 1 affect and, thus, encumber resource management projects including those designed to improve forest health up to 15 percent 
in late successional forests in all land allocations. Alternative 2 reduces that effect to about 5 percent and Alternative 3 reduces this effect to about 7 percent.

2. Alternatives 2 and 3 would also increase the Agencies' ability to plan and implement hazardous fuels treatment projects by increasing the acres available for treatment and reducing the costs of treatment. Under Alternative 2, the annual acres available for hazardous fuel treatments are projected at nearly 159,000, an increase of approximately 9,000 acres compared to Alternative 1 . Fuel treatment costs to manage for species would be $\$ 37$ per acre, a decrease of $\$ 57$ compared to Alternative 1 . Under Alternative 3, the annual acres available for hazardous fuel treatments would be 157,000, an increase of approximately 7,000 acres compared to Alternative 1. Fuel treatment costs to manage for species would be $\$ 29$ per acre, a decrease of $\$ 65$ compared to Alternative 1 .

\section{Public Involvement}

Public involvement with issues surrounding the Northwest Forest Plan has been long and detailed. To this knowledge base, and the experience with the 2000 Survey and Manage Final SEIS, the Agencies have added public and internal comments received during a 90-day public comment period following release of the Draft SEIS in May 2003.

\section{Scoping}

Scoping is the term used to identify issues, concerns, and opportunities associated with the proposed action in an environmental impact statement. According to the CEQ regulations, scoping is specifically not required for supplements to environmental impact statements (40 CFR 1502.9(c)(4)). However, the Agencies did conduct scoping for the SEIS. A Notice of Intent to prepare the SEIS was published in the Federal Register (63 FR 65167) on October 21, 2002. The Notice of Intent provided preliminary information about the proposed action and invited public comment. The Agencies received approximately 700 letters in response to the Notice of Intent and the letter.

This scoping helped define the issues and, subsequently, the range of alternatives presented in Chapter 2 of the Final SEIS.

\section{Public Comments on the Draft SEIS}

The public comment period for the Draft SEIS to Remove or Modify the Survey and Manage Mitigation Measure Standards and Guidelines began on May 23, 2003, and ended on August 22, 2003.

During the 90-day public comment period, approximately 5,100 transmittals were received in the form of letters, postcards, facsimiles, and e-mails (collectively referred to as letters). Letters were received from a variety of interests including: individuals, organizations, businesses, Advisory Committees, and Federal and State Agencies. Letters were received from 49 of the 50 states and from three foreign countries (Canada, England, and Germany). More than 3,000 letters originated from Washington, Oregon, and California. Thirty-eight letters were received after the close of the comment period. All letters were analyzed and considered in the preparation of the Final SEIS. An explanation of how comments were used is included in the Final SEIS in Appendix 6. Comment letters from other agencies, elected officials, tribes, and the California Coast Provincial Advisory Committee (PAC) are included in their entirety in Appendix 7 of the Final SEIS. 
Several areas of controversy were raised in comment letters. These areas of controversy with a brief explanation of how they were addressed in the Final SEIS are listed below. This is not a complete summary of all public comments received.

A "no old-growth harvest" alternative should be considered. The Final SEIS did not include a "no old-growth harvest" alternative because such an alternative is not suggested by the Need statement in the Final SEIS, and an alternative that did not harvest late-successional and old-growth forests was already considered in the 1994 Northwest Forest Plan Final SEIS (as Option 1).

The Agencies failed to use the best available science to develop this proposal. The Agencies used only federal "experts" in the Draft SEIS process. With the advent of the Survey and Manage Program, the Agencies hired or identified highly qualified taxonomic experts to assist in the overall management of the Survey and Manage program. Most of the identified experts have Ph.D.s, are tied to the Pacific Northwest Research Station, and remain engaged in the most recent research regarding their taxonomic group. Because this Final SEIS supplements the 2000 Final SEIS and the 1994 Northwest Forest Plan Final SEIS, it incorporates by reference the analysis and information provided by experts involved in those planning efforts. For the Northwest Forest Plan, this included panels of agency experts for each Survey and Manage taxa.

The outcomes in the Draft SEIS depend on an effective Special Status Species Programs. The effectiveness of these programs is questionable because of uncertain agency funding. The January 2004 Final SEIS assumes that the Special Status Species Programs will be implemented in accordance with existing policy. Since the Survey and Manage Program costs $\$ 15.9$ million more annually than the Special Status Species Programs, there is a larger risk that uncertain agency funding could negatively affect implementation of that program.

The SEIS assumes there will be similarities to outcomes for species under the Special Status Species Policies and Survey and Manage. This assumption is flawed because of the differences between the programs. While Survey and Manage requires on-the-ground surveys for approximately 70 species, the Special Status Species Policies allow for professional judgment and the use of other tools to determine the need for survey and the potential effect of the project upon the species at the project and population scale. In addition, the Special Status Species Policies allow for greater flexibility in how species sites are managed. Under the Special Status Species Policies, field-level biologists and botanists use their professional knowledge and the latest information (such as existing Management Recommendations) to make site-specific recommendations to their managers on how best to manage a site. It is not expected that professional judgment and greater flexibility will negatively affect overall species management objectives of the Special Status Species Policies. The flexibility allowed by professional judgment is still guided by the overall policy objective to ensure actions do not contribute to the need to list species under the Endangered Species Act and on National Forest System lands by Forest Service objectives for maintaining viable populations of vertebrate species in habitats distributed throughout the species range.

The Survey and Manage Program was revised in 2001. The changes have not been implemented long enough to know whether the program will prove effective. The purpose of the SEIS was not to analyze whether the Survey and Manage Mitigation Measure Standards and Guidelines are effective but to consider an alternative that removes them and relies on the Special Status Species Policies to achieve the goals of the Northwest Forest Plan through a more streamlined process. The 2000 Final SEIS did not analyze removing the Survey and Manage Mitigation Measure Standards and Guidelines.

If the Survey and Manage Mitigation Measure Standards and Guidelines are designed to help the Northwest Forest Plan to provide for a reasonable assurance of persistence of late-successional and old-growth forest associated species, why are they being eliminated? Is the important policy 
goal of protecting the long-term health and sustainability of federally managed forests within the range of the northern spotted owl and the species that inhabit them no longer important? The proposed action is intended to meet both needs identified in the Northwest Forest Plan, the need to provide for healthy forest ecosystems and the need for a sustainable supply of timber and other forest products. The fundamental elements of the Northwest Forest Plan species conservation strategy (reserves, Aquatic Conservation Strategy, and all other standards and guidelines) remain intact. Under Alternative 2, the Agencies' Special Status Species Policies provide for species management. Survey and Manage was only one of many mitigation measures identified in the Northwest Forest Plan. It largely is redundant to the existing programs designed to benefit such species.

The proposed changes eliminate a central element of the Northwest Forest Plan. The core elements of the Northwest Forest Plan are: (1) a network of late-successional and other reserves distributed across the landscape where management actions must protect or enhance late-successional forest conditions; (2) an aquatic conservation strategy providing for delineation of Riparian Reserves and other measures to protect or improve aquatic and riparian habitats over the long term; and, (3) a series of broadly stated standards and guidelines that guide management actions across the planning area or apply specifically outside reserve areas. Survey and Manage was not a central element of the Northwest Forest Plan; it is a mitigation measure that was added late in the planning process.

The Northwest Forest Plan was developed as a compromise between the timber industry and the environmental community. This proposal seeks to increase harvest levels while decreasing ecosystem protection, and eliminate that compromise. The purpose of the Northwest Forest Plan was to protect healthy forest ecosystems and produce a predicable and sustainable supply of timber from federally managed lands. Although some late-successional and old-growth forest in Matrix was designated for harvest as part of the 1.1 billion board feet estimated PSQ, about 86 percent of existing late-successional and old-growth forest is reserved. The alternatives in the January 2004 SEIS do not increase the harvest levels established in the Northwest Forest Plan. To the contrary; the analysis shows harvest levels would decrease under all alternatives as compared to the estimates made in the 1994 Northwest Forest Plan.

The ultimate result of Alternative 2 will be more species listed under the Endangered Species Act. The objectives of the Special Status Species Policies are for the Agencies' to avoid actions which may contribute to the need to list a special status species under the Endangered Species Act. Since the policies, are in place for all alternatives, we do not anticipate any more listings under Alternative 2 than would occur under any of the other alternatives.

Many other changes that affect land management are proposed at this time including the Aquatic Conservation Strategy SEIS, the Healthy Forest Restoration Act, and changes to the NFMA planning regulation. The Agencies must make an effort to address the cumulative effect of these changes in a single NEPA analysis. The analysis in the Final SEIS for proposed changes to the Aquatic Conservation Strategy showed no effects to species or the long-term health of the ecosystem. There is nothing in the Healthy Forest Restoration Act that exempts activities from meeting Northwest Forest Plan Standards and Guidelines. The Forest Service intends to issue NFMA implementing regulations in the near future. It is not anticipated that the amended regulations will affect this decision.

The Draft SEIS makes clear that the decision whether to add Survey and Manage species to the Special Status Species Programs is "separate from this proposal." This strategy is flawed because the ONRC v. Forsgren case and the Kern v. BLM case clearly point to the need for new analyses and updated land and resource management plans when significant species issues arise. The two referenced court decisions were preceded by another case which is more closely analogous to the present situation. In the Northcoast Environmental Center v. Glickman case, the Ninth Circuit Court affirmed the dismissal of an attempted NEPA challenge to 
an agency "program" for addressing the root disease affecting Port-Orford-cedar on the grounds that the Agencies had not prepared an EIS. The Ninth Circuit Court clarified that the time for challenging the agency's NEPA document was at the time an action was proposed that would actually affect the environment. Simply preparing a strategy for how the agency would address the issue in future plans was not "ripe" for judicial review. Similarly here, placing species on or off a list of species on which the BLM may have special concerns, has no environmental effect which itself must be analyzed first in a NEPA document. Only when the agency proposes some action or group of actions which would actually affect the physical environment of these species would there be a need for the agency to prepare a NEPA document.

The Agencies failed to consider the OEC Act of 1937 and the NFMA in making determinations of eligibility of the various species for inclusion in the Special Status Species Programs. Species become eligible for inclusion in these programs because of the criteria used by those programs for designating whether a species has "special status." The SEIS analytical assumptions simply recognize that some of these species will likely be incorporated into those programs because they are on state heritage lists and / or meet other criteria. The Special Status Species Policies are intended to work in conjunction with, and in accord with, existing authorities of the Agencies in managing public lands. Simply determining eligibility of species for inclusion in these special programs does not conflict with those authorities.

\section{Administrative Review or Appeal}

A decision by the Under Secretary of Agriculture is not subject to administrative appeal under the Forest Service regulations. A decision by the Assistant Secretary of the Interior is not subject to administrative review under BLM or Departmental regulations. Therefore, this is the final decision by the Agencies for removing the Survey and Manage Mitigation Measure Standards and Guidelines from the applicable planning documents.

This decision does not constitute the final agency action for any ground-disturbing project or activity. Before a decision document for a project or activity, such as a timber sale or restoration project, is authorized, applicable procedures must be complied with, including applicable project-level NEPA analysis and administrative appeal procedures.

\section{Authority to Amend or Modify this Decision}

As with other parts of the Northwest Forest Plan, amendments to forest and district land and resource management plans that would modify the land management direction established by this Record of Decision will be coordinated through the Regional Interagency Executive Committee (RIEC) as described in the original Northwest Forest Plan Record of Decision.

\section{Effective Date}

This decision shall take effect 30 days after the last date of signature of this Record of Decision. 
11. Contact

Lisa Freedman

Director of Resource Planning and Monitoring

USDA Forest Service

Pacific Northwest Region

P.O. Box 3623

Portland OR 97208-3623

Mike Haske

Branch Chief for Natural Resources

Oregon/ Washington State Office

P.O. Box 2955

Portland, OR 97208-2955

12. Signatures and Dates

By signing this Record of Decision together, we exercise our respective authorities over only those portions relevant to our authority.

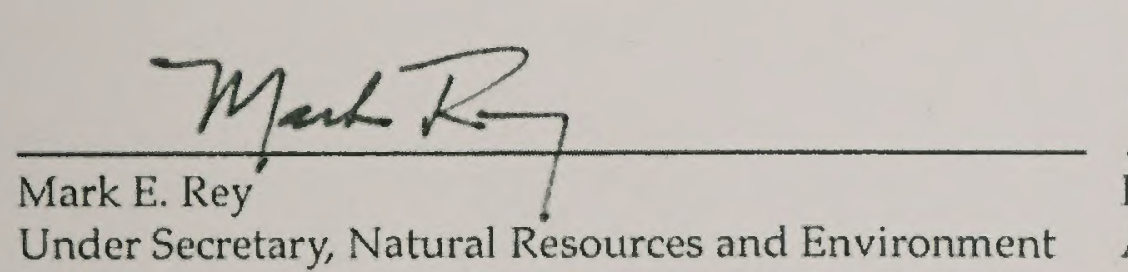

U.S. Department of Agriculture

Dated:

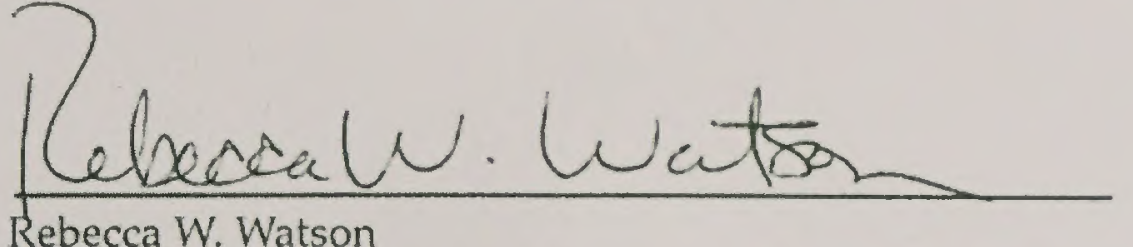

Rebecca W. Watson

Assistant Secretary, Land and Minerals Management U.S. Department of the Interior Dated:

MAR 222004

MAR 222004

29 
Record of Decision to Remove or Modify the Survey and Manage Mitigation Measure Standards and Guidelines 


\section{Standards and Guidelines}

for Certain Cavity-Nesting Birds Canada Lynx and Some Bat Roosts

and

Management Recommendations

for Certain Cavity-Nesting Birds and Some Bat Roosts 
Record of Decision to Remove or Modify the Survey and Manage Mitigation Measure Standards and Guidelines 


\section{Standards and Guidelines \\ for \\ Certain Cavity-Nesting Birds, Canada Lynx, and some Bat Roosts}

and

\section{Management Recommendations}

for

Certain Cavity-Nesting Birds

and some Bat Roosts

March 2004

\section{Appendix 1}

\section{to the Record of Decision \\ to Remove or Modify the Survey and Manage Mitigation Measure Standards and Guidelines}

This appendix contains Sections IX, X, and XI from Attachment 1 of the January 2001 Record of Decision. These sections deal with certain cavity-nesting birds, Canada lynx, and some bat roosts. These sections were not proposed for removal or modification by any of the alternatives in the January 2004 Final SEIS. These standards and guidelines and management recommendations remain in effect.

Minor edits have been made to alter references to standards and guidelines that are removed by this (February 2004) Record of Decision. 
Record of Decision to Remove or Modify the Survey and Manage Mitigation Measure Standards and Guidelines 


\section{White-headed woodpecker, Black- backed woodpecker, Pygmy nuthatch, and Flammulated owl}

\section{Standard and Guideline}

The white-headed woodpecker, black-backed woodpecker, pygmy nuthatch, and flammulated owl will not be sufficiently aided by applying mitigation measures for riparian habitat protection or other elements of the Northwest Forest Plan. These four species occur on the periphery of the range of the northern spotted owl on the east slope of the Cascade Range in Washington and Oregon. Additionally, the white-headed woodpecker and flammulated owl occur in the Klamath Provinces in northwestern California and southwestern Oregon.

To ensure that the distribution and numbers of all four species do not decline on BLM Districts and National Forests within the range of the northern spotted owl, adequate numbers of large snags and green-tree replacements for future snags in appropriate forest types within the range of these four species will be maintained in sufficient numbers to maintain 100 percent of potential population levels of these four species.

Specific application details are relegated to the Management Recommendation so they may be more easily kept current with existing science, experience, and species status. The Management Recommendation provides specific instructions for meeting the objectives and requirements of this standard and guideline. Management Recommendations for these species may be revised as new information warrants. Changes to Management Recommendations are subject to review by the REO.

\section{Management Recommendation}

These species will not be sufficiently aided by application of mitigation measures for riparian habitat protection or for marbled murrelets alone. They all occur on the periphery of the range of the northern spotted owl on the east slope of the Cascade Range in Washington or Oregon. Additionally, the white-headed woodpecker and flammulated owl occur in the Klamath Province in northwestern California and southwestern Oregon. The viability of all four species within the range of the northern spotted owl was rated as a medium risk on National Forests, although they each are much more widely distributed elsewhere.

Apply the following mitigation standards and guidelines to ensure that the distribution and numbers of all four species do not severely decline on BLM Districts and National Forests within the range of the northern spotted owl. These guidelines apply to the forest matrix outside designated habitat for the northern spotted owl and Riparian Reserves. Maintain adequate numbers of large snags and green-tree replacements for future snags within the four species' ranges in appropriate forest types. Where feasible, green-tree replacements for future snags can be left in groups to reduce blowdown. Specifically, snags over 20 inches dbh are particularly valuable for these species. Snags over 20 inches dbh may be marked for cutting only after retaining the best available snags (considering size, longevity, etc.) in sufficient numbers to meet 100 percent of potential population levels of these four species. It is recognized, however, that safety considerations may prevent always retaining all snags. Use of standardized definitions of hazard trees is required. For the longer term, provide for sufficient numbers of green trees to provide for the full (100 percent) population potential of each species. 
As depicted by Neitro in Management of Wildlife and Fish Habitats in Forest of Western Oregon and Washington (1985), the 100 percent population potential for white-headed woodpeckers is 0.60 conifer snags (ponderosa pine or Douglas-fir) per acre in forest habitats; these snags must be at least 15 inches dbh (or largest available if 15 inch dbh snags are not available) and in soft decay stages, and must be provided in stands of ponderosa pine and mixed pine/Douglas-fir. The 100 percent population potential for black-backed woodpeckers is 0.12 conifer snags per acre in forest habitats; these snags must be at least 17 inches dbh (or largest available if 17 inch dbh snags are not available) and in hard decay stages, and must be provided in stands of mixed conifer and lodgepole pine in higher elevations of the Cascade Range. However, the snag numbers representing 100 percent potential population levels cited from Neitro must be updated as appropriate new references become available. Provision of snags for other cavitynesting species, including primary cavity-nesters, must be added to the requirements for these two woodpecker species. Site-specific analysis, and application of a snag recruitment model (specifically, the Forest Service's Snag Recruitment Simulator) taking into account tree species, diameters, falling rates, and decay rates, will be required to determine appropriate tree and snag species mixes and densities. If snag requirements cannot be met, then harvest must not take place.

As identified by the expert FEMAT panel, black-backed woodpeckers also require beetle infested trees for foraging; some such trees should be provided in appropriate habitat, and sanitation harvest of all such trees would be detrimental to the species. More information is needed on habitat use, seasonal occurrence, and use of forest age classes and burns, for the black-backed woodpecker.

Pygmy nuthatches use habitat very similar to those of white-headed woodpeckers. Pygmy nuthatches require large trees, typically ponderosa pine within the range of the northern spotted owl, for roosting. Provision of snags for white-headed woodpeckers is assumed to provide for the needs of pygmy nuthatch, as no species-specific guidelines for the species have been developed. Additional information on ecology of pygmy nuthatch within the range of the northern spotted owl is needed to develop more precise standards and guidelines.

Flammulated owls are secondary cavity-nesters and use cavities, in snags and live trees, created by woodpeckers or, less often, that occur naturally. It is assumed that standards and guidelines for snags and green-tree replacements for woodpeckers and other primary cavity-nesting species, as provided by existing BLM Resource Management Plans and National Forest Land and Resource Management Plans and for the woodpeckers in this species group, would provide for flammulated owls.

Note: The snag recommendations above are based on the model presented by Neitro and others (1985). In that model, snag requirements for individual species were treated as additive in developing snag requirements for the overall community of cavity excavators. As noted above, "provision of snags for other cavity-nesting species, including primary cavity nesters, must be added to the requirements for these two woodpecker species" (black-backed and white headed woodpeckers).

Snag requirements are developed by the BLM Districts and National Forests for specific forest cover types, and these may be further broken down by geographic location. The intent is to tailor the requirements to those species that are actually expected to occur in an area. To determine if the protection buffer requirements should be added to existing BLM or Forest Service land use plan requirements, the basis for those existing requirements should be analyzed to determine if they include the species identified by the 1993 Forest Service Scientific Analysis Team (SAT) at the specified level of percent population potential. If they do not, then the SAT requirements must be added to the existing BLM or Forest Service land use plan requirements. 


\section{Canada lynx}

\section{Standard and Guideline}

\section{Proposed Actions}

The Forest Service will follow the conservation agreement for the Canada lynx in making any new decision to undertake actions affecting Canada lynx or their habitat, and to fully meet their Endangered Species Act, National Forest Management Act, and National Environmental Policy Act responsibilities. A proposed or new action is one for which a federal agency does not yet have a decision notice, record of decision, or decision memo. Major features of this conservation agreement include:

For actions on National Forest System lands which are proposed by and/or involve third parties, such as pipeline corridors, access requests, issuance of new authorizations upon expiration of existing authorizations or permits, etc., the Forest Service, in consultation with the U.S. Fish and Wildlife Service, agrees to review and consider the new information on the Canada lynx included in the Lynx Conservation Assessment and Strategy, the Science Report, and appropriate local information to ensure compliance with all applicable federal laws, including the Endangered Species Act, National Environmental Policy Act, and the National Forest Management Act, during the Agency's analysis and decision-making processes. Grazing permits subject to Section 504 of the 1995 Rescissions Act will be issued consistent with that Act.

For actions on National Forest System lands which are proposed by the Forest Service and do not involve third parties, an evaluation of the action will be prepared using relevant new information, including the Lynx Conservation Assessment and Strategy and the Science Report, to determine whether the activity may affect Canada lynx. The Lynx Conservation Assessment and Strategy will be used and referenced in all determinations of effect for Canada lynx. If the evaluation indicates an activity is likely to adversely affect the lynx, the Agency will not authorize the activity until plans are revised or amended as described in Part 2 of the Canada Lynx Conservation Agreement to include Canada lynx conservation standards.

The Forest Service, in cooperation with the U.S. Fish and Wildlife Service, will look for opportunities to undertake proactive management actions to benefit Canada lynx based on the Lynx Conservation Assessment and Strategy, to the extent they are consistent with current land and resource management plans.

\section{Ongoing Actions}

All agency actions in suitable Canada lynx habitat that have gone through agency planning processes and have a documented agency decision (decision memo, decision notice, or record of decision) will be reviewed, based on new information on the Canada lynx, including that in the Lynx Conservation Assessment and Strategy and Science Report, as appropriate, to ensure compliance with the Endangered Species Act, National Forest Management Act, National Environmental Policy Act, and other applicable laws.

Note: The complete text of the Forest Service/U.S. Fish and Wildlife Service conservation agreement, the Canada Lynx Conservation Assessment and Strategy, and the Lynx Science Report, The Scientific Basis for Lynx Conservation (Ruggiero et al. 1999), are available on the web at: www.fs.fed.us/r1/planning/lynx/lynx.html. 
The BLM has recently reviewed its evaluations of potential suitable lynx habitat on lands it administers within the species suspected tange in the planning area. Based upon criteria for identifying and mapping suitable habitat as recommended by the Lynx Science Team, this recent review has concluded that no suitable lynx habitat occurs on BLM administered lands in the planning area.

\section{Provide Additional Protection for Caves, Mines, and Abandoned Wooden Bridges and Buildings that are Used as Roost Sites for Bats}

\section{Standard and Guideline}

Most bat species occurring in the Pacific Northwest roost and hibernate in crevices or caverns in protected sites. Suitable roost sites and hibernacula fall within a specific range of temperature and moisture conditions. Sites commonly used by bats include caves, mines, snags and decadent trees, wooden bridges, and old buildings. Provisions for retention of large snags and decadent trees are included in the standard and guideline for green tree patches in the Matrix. Caves and abandoned mines, wooden bridges and buildings, however, are extremely important roost and hibernation sites for which additional feasible protection measures are required to ensure their value as habitat is maintained.

This standard and guideline applies to all bat species that would benefit and that the reserves and other standards and guidelines of the Northwest Forest Plan may not provide a reasonable assurance of persistence. In all land allocations, protect caves, and abandoned mines, wooden bridges and buildings used by bats from destruction, vandalism, and disturbance from road construction or blasting, or other activities that could change microclimate conditions or drainage patterns affecting use by bats. Protection of these structures must be contingent on safety concerns and legal requirements. Management of occupied sites will be consistent with the bats Management Recommendation. Site-specific roost plans based on inventory and mapping of resources will be completed when such plans are a needed tool to protect or mitigate roost habitat for bats.

The Management Recommendation provides specific instructions for meeting the objectives and requirements of this standard and guideline. Management Recommendations for these species may be revised as new information warrants. Revisions would be reviewed by the REO. The Management Recommendations may include guidelines for: (1) conducting searches; (2) identifying likely bat use; (3) identifying appropriate circumstances for species identification; (4) establishing conditions under which specific mitigation measures will be applied to project activity plans; (5) describing various no-harvest buffer widths to fit specific habitat conditions; or, (6) other guidelines to help determine site-specific management needs.

For the purposes of this standard and guideline, caves are defined as in the Federal Cave Resources Protection Act of 1988 as:

"Any naturally occurring void, cavity, recess, or system of interconnected passages which occur beneath the surface of the earth or within a cliff or ledge ( . . but not including any 
... man-made excavation) and which is large enough to permit an individual to enter, whether or not the entrance is naturally formed or man-made."

\section{Management Recommendation}

This Management Recommendation is intended to provide additional feasible protection for roost sites for bats including the fringed myotis, silver-haired bat, long-eared myotis, long-legged myotis, pallid bat, and Townsend's big-eared bat. This species list should be revised as necessary to include other bat species that: (1) would benefit from inclusion in this standard and guideline, and (2) the reserves and other standards and guidelines of the Northwest Forest Plan may not provide a reasonable assurance of persistence.

The Agencies will determine if each cave, abandoned mine, abandoned wooden bridge, and abandoned building that may be affected by the Agencies' management activities warrants management as an occupied bat site. To make this determination, the Agencies may either conduct non-intrusive surveys to determine presence of bats, or may presume presence where conclusive surveys are not conducted. Criteria for defining nonintrusive surveys, survey conclusiveness and occupancy are to be described in the Survey Protocols and Management Recommendations, as appropriate. Individual species identification is not required in order to presume occupancy by target species. For sites occupied by bats, the Agencies will prohibit timber harvest within 250 feet of the site, and develop management direction for the site, as necessary, that includes an inventory and mapping of resources, and plans for protection of the site from vandalism, disturbance from road construction or blasting, and any activity that could change cave temperatures or drainage patterns. The size of the buffer, and types of activities allowed within the buffer, may be modified through the management direction developed for the specific site.

Townsend's big-eared bats are of concern to state wildlife agencies in both Washington and Oregon. These bats are strongly associated with caves, and are extremely sensitive to disturbance, especially from recreational cavers. When Townsend's big-eared bats are found occupying caves or mines on federal land, the appropriate state agency should be notified, and management prescriptions for that site should include special consideration for potential impacts on this species. 
Record of Decision to Remove or Modify the Survey and Manage Mitigation Measure Standards and Guidelines 


\section{Errata}

One of the fungi species, Phaeocollybia californica, was inadvertently omitted from Table $2-5$ on page 55 of the Final SEIS.

Phaeocollybia californica should be listed with an SS designation for the BLM OR/WA and BLM CA columns and an SS-O designation for the FS R-6 column. This information was included in the Final SEIS on Table 2-6 (p.60). 
Record of Decision to Remove or Modify the Survey and Manage Mitigation Measure Standards and Guidelines 
43 
BLM Library

Denver Federal Center

Bldg. 50, OC-521

P.O. Box 25047

Denver, CO 80225 



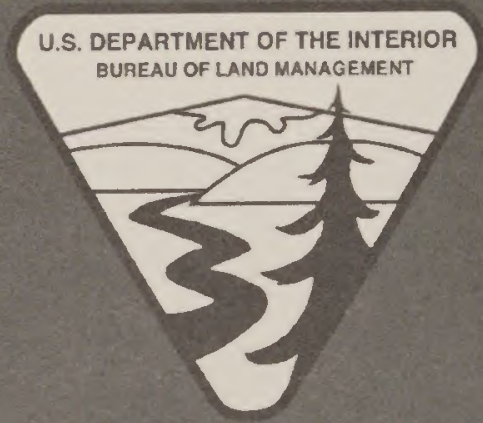

UNITED STATES DEPARTMENT OF THE INTERIOR

BUREAU OF LAND

MANAGEMENT

333 S.W. 1st Avenue

Portland, Oregon 97204

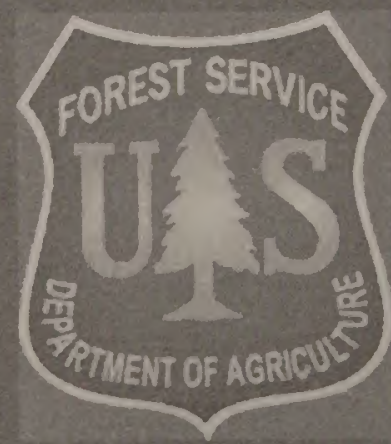

UNITED STATES DEPARTMENT OF AGRICULTURE FOREST SERVICE

333 S.W. 1st Avenue

Portland, Oregon 97204

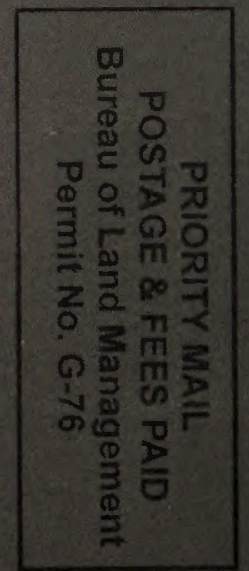

